Summer 2015

\title{
Austerity, the European Council, and the Institutional Future of the European Union: A Proposal to Strengthen the Presidency of the European Council
}

\author{
Federico Fabbrini \\ University of Copenhagen, federico.fabbrini@jur.ku.dk
}

Follow this and additional works at: https://www.repository.law.indiana.edu/ijgls

Part of the Election Law Commons, European Law Commons, International Law Commons, and the Transnational Law Commons

\section{Recommended Citation}

Fabbrini, Federico (2015) "Austerity, the European Council, and the Institutional Future of the European Union: A Proposal to Strengthen the Presidency of the European Council," Indiana Journal of Global Legal Studies: Vol. 22 : Iss. 2 , Article 3.

Available at: https://www.repository.law.indiana.edu/ijgls/vol22/iss2/3

This Symposium is brought to you for free and open access by the Law School Journals at Digital Repository @ Maurer Law. It has been accepted for inclusion in Indiana Journal of Global Legal Studies by an authorized editor of Digital Repository @ Maurer Law. For more information, please contact rvaughan@indiana.edu. 


\title{
Austerity, the European Council, and the Institutional Future of the European Union: A Proposal to Strengthen the Presidency of the European Council
}

\author{
FEDERICO FABBRINI ${ }^{*}$
}

\begin{abstract}
This article contextualizes the resilience of austerity in Europe, explaining it in light of the transformations in the $E U$ system of governance. As the article maintains, since the eruption of the Eurocrisis, the European Council-the body congressing the heads of state and government of the EU member states together with its President and the President of the European Commission-has risen to the center of EU governance. In an intergovernmental institution such as the European Council, however, larger and wealthier states have been able to impose their preferences on other states-a development that is at odds with the anti-hegemonic nature of the EU integration project. To address this problematic state of affairs, this article proposes a targeted institutional reform: strengthening the President of the European Council. As this article claims, a President of the European Council endowed with its

* Associate Professor of European and International Law, iCourts (Center of Excellence on International Courts), Faculty of Law, University of Copenhagen. Earlier versions of this article were presented at the annual symposium of the Indiana Journal of Global Legal Studies at the Indiana University Maurer School of Law in Bloomington, IN, on September 11-12, 2014; at the Michaelmas term opening seminar of the Center for European Legal Studies at the University of Cambridge in Cambridge, U.K., on October 15, 2014; and at the comparative constitutional law roundtable held at the Center for the Study of the Constitution in James Madison's Montpelier-Orange, VA on October 17-18, 2014. In writing this article I greatly benefitted from the comments and criticisms I received from a number of colleagues and friends, including Eric Alston, Fred Aman, Kenneth Armstrong, Mathilde Cohen, Paul Craig, Erin Delaney, Antonio Estella, Sergio Fabbrini, Catarina Frade, Markus Gehring, Vicki Jackson, Daniel Kelemen, Jud Matthews, Russ Miller, Vlad Perju, Paul Posner, Uwe Puetter, Al Roberts, Or Rosenboim, Bill Scheuerman, Nicole Schreier, Julie Suk, Ozan Varol, and Mila Versteeg. Needless to say, all errors remain my own. Further comments are welcome at federico.fabbrini@jur.ku.dk.
\end{abstract}

Indiana Journal of Global Legal Studies Vol. 22 \#2 (Summer 2015)

c) Indiana University Maurer School of Law 
own executive powers and legitimated by a popular election could restore a balance between the member states and, at the same time, create a forum for democratic contestation of the policies of the European Union. The proposal to strengthen the presidency of the European Council builds on recent calls to redefine this institution as the presidency of the European Union as a whole. However, it faces several challenges. This article considers the following questions: 1) What are the advantages associated with the proposal to strengthen the European Council presidency and what powers should be attributed to the office?; 2) What electoral mechanism could be conceived to select the President in an asymmetrical Union of states and citizens?; and 3) What are the incentives-and is there a window of opportunity-to implement this reform? This article proposes ways to address these issues, opening a debate on a potentially fruitful constitutional reform of the EU system of governance.

\section{INTRODUCTION}

The causes of the recent economic and financial crisis, and the best way to respond to it, are at the heart of heated debates in both the United States and the European Union. While economists have clashed on topics such as austerity, debt, and the role of central banks, ${ }^{1}$ the latest proof of the fundamental disagreement between policy makers was prominently on display at the meetings of the Group of 20 (G20) and International Monetary Fund (IMF) in fall 2014. Here, U.S. officials-supported by representatives of EU countries such as France and Italy-pushed for expansionary economic and monetary policies to tackle the risk of global stagnation, but were rebuffed by Germany and the United Kingdom, which advanced instead an economic blueprint based on budget cuts and structural reforms as a way out of the crisis. ${ }^{2}$

1. In the United States, compare CARMEn M. REINHART \& KenNETH S. Rogoff, ThIS Time is Different: Eight Centuries of FinANCIAL Folly (2009) (arguing that higher levels of public debt are responsible for economic contraction), with PAUL KRUGMAN, END THIS DEPRESSION Now! (2012) (defending a Keynesian view, which advocates public spending to boost growth and criticizes austerity). In the EU context, compare HANSWERnER SINN, THE EURo TRAP (2014) (criticizing expansionary policies by the European Central Bank, hailing structural reforms and making the case for the exit of some member states from the Eurozone), with MARTIN WOLF, THE SHIFTS AND THE SHOCKS (2014) (defending expansionary monetary policy).

2. See generally Mike Peacock, Austerity Versus Growth Version 3.0 at G20/IMF, REUTERS (Oct. 5, 2014, 6:23 AM), http://www.reuters.com/article/2014/10/05/us-globaleconomy-idUSKCNOHU06E20141005 (discussing the debate in the context of the G20 between those favoring austerity measures and those favoring policies intended to foster economic growth). 
Other contributions to this symposium on "Law and the Globalization of Austerity" discuss the economic and political arguments pro or against austerity, both nationally and globally. This article will not address those issues. Rather, this article focuses on constitutional questions that are raised by the policy of austerity, and which specifically concern the institutional set up of the European Economic and Monetary Union (EMU).

This article seeks to contextualize the European focus on the policy of austerity within a broader discussion of how the institutional framework of the European Union has evolved during the Euro-crisis, shifting power among the EU member states, as well as among the EU institutions. As this article explains, the resilience of austerity in the European Union's responses to the crisis results from growing power imbalances among EU member states and reflects Germany's increasing centrality in the EU policy-making process. Austerity closely matched long-standing and short-term economic preferences of Germany-the largest and wealthiest EU Member State. Despite the increasing protests against and opposition to austerity in many EU member states, Germany has been able to entrench this economic strategy in EU law and policy. Nevertheless, the shift of power among the EU member states reflected by the policy of austerity reveals a deeper institutional evolution in the architecture of the European Union. Accelerating developments that were already embedded in the EU Maastricht Treaty of 1992, the Euro-crisis has brought to the forefront the European Council-the EU body that congresses the heads of states and governments of the EU member states, together with its President and the President of the European Commission. ${ }^{3}$ During recent years, the European Council has emerged as the center of EU policy making in the economic domain and has displaced the other EU institutions as the agenda setter on how to respond to the crisis.

Yet, as this article maintains, the rise of an intergovernmental body such as the European Council has weakened the traditional checks and balances that characterized the functioning of the European Union. In particular, the management of the Euro-crisis by the European Council

3. See Consolidated Version of the Treaty on European Union art. 15(2), Oct. 26, 2012, 2012 O.J. (C 326) 1 [hereinafter TEU]. Readers who are not experts in EU law should pay attention to the fact that the European Council should not be confused with the Council of the EU (or simply: the Council). While the former is an executive body composed of prime ministers and heads of state (plus its own President and the President of the European Commission), the latter is an institution exercising mainly legislative power (as well as, however, administrative powers) and which brings together national ministers, in various compositions, depending on the subject matter which is being deliberated (e.g., agriculture, foreign affairs, etc.). See id. art. 16 (defining the role and composition of the Council). 
has brought to light a dynamic of interstate domination since, in an intergovernmental framework, state powers matter and thus stronger states have greater influence over decisions. As this article claims, this dynamic strikes at the heart of the project of EU integration. Regardless of the specific substantive choices reflected by the policy of austerity, a regime in which some states are structurally dominating the policymaking process undermines the anti-hegemonic ideal on which the European Union was built, and generates decisions that are perceived as illegitimate by those states and citizens that have no way to influence the outcome of the policy-making process. Beyond the specific problem that the resilience of austerity in the European Union poses, the new allocation of powers among the EU institutions, and among the EU member states, has brought to light a structural constitutional problem in the European Union. Addressing this problem constitutes an urgent need to ensure the enduring sustainability of the European Union.

In order to address this problem, this article proposes an institutional reform and makes the case in favor of strengthening the role of the President of the European Council. If the European Council has become the central institution in deciding the economic policy of the European Union, efforts should be made to prevent this institution from being captured by specific state preferences, and the role of the presidency should be explored to this end. While under the current constitutional set up the President of the European Council only enjoys limited authority, this office should be reformed and endowed with greater executive powers of its own, including the task to set the policy agenda of the European Union. At the same time, these greater powers should be counterbalanced by a new democratic mechanism for electing the President that entrusts the office with the legitimacy to act in the name of the European Union as a whole. Compared to other recent options of institutional reform, including the efforts to politicize the President of the European Commission by transforming the European Union into a parliamentary regime, the proposal to strengthen the President of the European Council along a constitutional logic of separation of powers is better suited to keep in check the larger member states within the European Council. A stronger, directly legitimated presidency would prevent the dynamics of domination that the crisis brought to the fore and, at the same time, could create a genuine forum for democratic competition and contestation of the EU agenda.

The proposal to strengthen the presidency of the European Council revives ideas already advanced during the European Constitutional Convention of $2002-2003.4$ At the same time, the proposal is

4. See infra p. 300. 
emboldened by the recent calls to redefine the role of the President of the European Council as the President of the European Union as a whole. ${ }^{5}$ Nevertheless, I am mindful of the difficulties that any such program of institutional change would meet in today's European Union. As such, this article also considers three challenges that would arise along the road toward strengthening the presidency of the European Council. First, there exists a challenge of representation connected to the difficulties of providing an electoral forum in which presidential candidates can represent, and thus frame, alternative visions for the governance of the European Union. Second, there is a challenge of asymmetry related to the need to design a system for electing the President of the European Council that is able to account for, and yet balance, the asymmetrical size of the EU member states' populations. Third, there is a challenge of unanimity related to the difficulty of introducing the reform proposed in this article in the current EU system, given the need to obtain the unanimous agreement of all member states. This article considers each of those difficult challenges. It accepts that none of them has an easy solution. Yet, this article submits that it is time for a serious discussion about how the EU system of governance should be reformed to improve its effectiveness and legitimacy.

The resilience of austerity in Europe is just the surface of a structural, tectonic shift in the architecture of the European Union. The European Council has emerged as the main EU institution in charge of defining the policy agenda of the European Union. Yet, the rise of the European Council has not been an unproblematic development. In a framework of intergovernmental governance, some states have been able to dominate the policy-making process, challenging at its core the anti-hegemonic nature of the European integration project. Regardless of whether one agrees with the policy of austerity promoted by the European Council to address the crisis, an institutional regime in which interstate relations are increasingly unbalanced threatens to undermine the sustainability of the European Union. A necessary step to address this problem is a constitutional reform of the EU architecture. The proposal to strengthen the power and legitimacy of the President of the European Council along the constitutional logic of separation of powers may be the best option to redress the problem of interstate domination, and to create a genuine space for democratic contestation on the agenda of the European Union.

This article is structured as follows. Part I explains the resilience of austerity in the European Union's responses to the Euro-crisis in light

5. See infra p. 299. 
of the growing imbalance between the member states and the central position that Germany has come to play in the EU decision-making process as far as economic policy is concerned. Part II zooms back and clarifies how austerity is just the evidence of a broader institutional transformation in the EU architecture, which has seen the European Council rise to the center of EU policy making. Part III argues that the current EU institutional setup has produced a problematic dynamic of interstate domination that challenges at its heart the nature of the European Union. To address that situation, therefore, I make the case in favor of strengthening the presidency of the European Council and argue that this reform could reestablish a balance between the member states and secure a forum for democratic contestation on the EU agenda. Subsequent sections then develop this proposal and discuss specific challenges. Hence, Part IV considers how an effective and legitimated President of the European Council could solve the EU representation deficit and defines which new powers should be attributed to the office. Part V dwells on the mechanics of the election of the President of the European Council in light of the profound asymmetry in the population of the EU member states. Part VI considers whether the proposal to strengthen the presidency of the European Council could win the unanimous consensus needed for treaty change, suggesting that the reform of the EMU provides a window of opportunity, and advancing pragmatic and institutional arguments to have all the member states sign off on the proposal. A brief conclusion follows.

\section{INTERSTATE RELATIONS AND THE RESILIENCE OF EUROPEAN AUSTERITY}

Scholars and analysts have emphasized that austerity has been the main economic blueprint followed in Europe to address the crisis. ${ }^{6}$ Although the causes of the Euro-crisis are contested, the main narrative that has prevailed in the European Union since 2009 blames the deterioration of the European economy on the irresponsible fiscal behavior of several member states. Of course, as Miguel Maduro has argued, ${ }^{7}$ another plausible narrative of the crisis could have put the

6. See, e.g., JEAN PISANI-FERRY, The Euro CRISIS AND ITS AFTERMATH (Cristophe Gouardo trans., 2014); Benjamin M. Friedman, The Pathology of Europe's Debt, 61 N.Y. REV. BoOKS, Oct. 9, 2014, at 50.

7. See Miguel Poiares Maduro, A New Governance for the European Union and the Euro: Democracy and Justice, report commissioned by the Constitutional Affairs Committee of the European Parliament PE 462.484 (Sept. 2012) (contrasting a narrative of the crisis based on excessive spending by some states with one based on irresponsible lending by some banks). 
blame on the banking sector and its irresponsible lending to debtors who lacked sufficient creditworthiness. Nevertheless, the EU institutions and the member states unequivocally responded to the crisis as if this were purely a problem of sovereign debt. ${ }^{8}$ As a result, austerity $\longrightarrow$ or fiscal consolidation, the idea that national governments must slash deficits and restructure public expenditures as a way to restore a sustainable path towards economic expansion-has become the official credo in responding to the crisis. ${ }^{9}$ In fact, legal reforms of the EMU have largely codified this view: ${ }^{10}$ As Paul Craig has explained, new EMU rules have compelled member states to constitutionalize a balanced budget amendment, strengthened the oversight of supranational authorities over the budgetary processes of the member states, and imposed tough programs of economic adjustment on countries on the brink of default that were recipients of financial support. ${ }^{11}$

Extensive literature discusses the design and implementation of austerity policy in the European Union following the Euro-crisis. Some observers have underlined a positive side to the story-particularly in promoting structural reforms in countries like Italy, where the economy was traditionally overburdened by a gigantic public sector and by strong political resistance to reform. ${ }^{12}$ Nevertheless, many others have emphasized the negative effects that austerity measures produced on the welfare state, especially in countries such as Greece, Portugal, or

8. See Jan Windebank \& Adam Whitworth, Social Welfare and the Ethics of Austerity in Europe: Justice, Ideology and Equality, 22 J. CONTEMP. EUR. STUD. 99, 99 (2014); Editorial, Europe's Recurring Malaise, N.Y. TIMES, Aug. 18, 2014, at A18, available at http://www.nytimes.com/2014/08/18/opinion/europes-recurring-malaise.html?_r=0.

9. See generally Alberto Alesina \& Silvia Ardagna, Tales of Fiscal Adjustments, 27 ECON. POL'Y 489 (1998), for an articulated academic explanation of the so-called theory of expansionary austerity. As reported by Peter Coy, Professor Alesina gave a presentation of an updated version of his paper to the Ministers of Finance of the EU member states at their meeting in Madrid on April 17, 2010. See Peter Coy, Keynes vs Alesina. Alesina Who?, BLOOMBERG BUS. (June 29, 2010), http://www.bloomberg.com/bw/stories/2010-0629/keynes-vs-dot-alesina-dot-alesina-who.

10. See Federico Fabbrini, The Fiscal Compact, the "Golden Rule," and the Paradox of European Federalism, 36 B.C. INT'L \& COMP. L. REV. 1 (2013).

11. See Paul Craig, Economic Governance and the Euro Crisis: Constitutional Architecture and Constitutional Implications, in THE CONSTITUTIONALIZATION OF EUROPEAN BUdGetaRy CONSTRaINTS 19, 21-22 (Maurice Adams, Federico Fabbrini \& Pierre Larouche eds., 2014).

12. See, e.g., Vincenzo Visco, Governor It. Cent. Bank, Considerazioni Finali, Speech at the Banca d'Italia (May 30, 2014), available at https:/www.bancaditalia.it/ pubblicazioni/interventi-governatore/integov2014/cf13_considerazioni_finali.pdf

(emphasizing opportunities created by the crisis for reforms). 
Spain, where unemployment soared to unprecedented levels. ${ }^{13}$ Be that as it may, during the last years, the policy of austerity has increasingly come under attack. Massive street demonstrations and national strikes against austerity policy were organized in Athens and Madrid. ${ }^{14} \mathrm{New}$ national governments were elected on anti-austerity platforms in Paris and Rome. ${ }^{15}$ And growing emphasis on the need for growth policies was voiced in Brussels ${ }^{16}$ as well as in Washington. ${ }^{17}$ These events have certainly signaled increasing political discontent with the European strategy for tackling the crisis ${ }^{18}$ and have raised awareness about the dire problem of youth unemployment. ${ }^{19}$ Nevertheless, they have not fundamentally changed the status quo, with austerity remaining the default economic policy of the European Union. Why is that so?

To explain the resilience of austerity policy in the European Union notwithstanding the growing discontent and opposition against it, we need to understand the changing relationship among the EU member states since the crisis. As I have explained elsewhere, ${ }^{20}$ the Euro-crisis and the political and legal responses to it have produced important constitutional implications for the horizontal relations of powers among the EU member states. Whereas the EU institutional system had

13. See, e.g., Kilaus Buch et al., EURo Crisis, Austerity Policy and the European SOCIAL MODEL: How CRISIS IN SOUTHERN EuROPE THREATENS THE EU'S SocIaL DIMENSION (2013) (discussing the restrictions that austerity policies produce on the welfare state).

14. See Graeme Wearden, Europe's Day of Anti-Austerity Strikes and Protests Turn Violent, THE GUARDIAN (Nov. 14, 2012, 12:31 AM), http://www.theguardian.com/business/ 2012/nov/14/eurozone-crisis-general-strikes-protest-day-of-action (reporting massive strikes in cities across Europe and episodes of violence).

15. See Andrew Higgins, Europe Pressed to Reconsider Cuts as a Cure, N.Y. TIMES, Apr. 27, 2013, at A1, available at http:/www.nytimes.com/2013/04/27/world/europe/eu-ispressed-to-reconsider-cuts-as-economic-cure.html?pagewanted=all\&_r $=0 \quad$ (discussing increased political malaise vis-à-vis the policy of austerity so far adopted to address the Euro-crisis).

16. See, e.g., European Parliament Resolution on the Enquiry on the Role and Operations of the Troika (ECB, Commission, and IMF) with Regard to the Euro Area Programme Countries, PARL. EUR. DOC. P7_TA(2014)0239 (2014) (criticizing the policy promoted by the troika in the EU member states subject to economic adjustment programs).

17. See generally Int'l Monetary Fund [IMF], Toward a Fiscal Union for the Euro Area, SDN/13/09 (Sept. 2013) (suggesting the need to develop a fiscal capacity at the EU level to boost growth).

18. See Federico Fabbrini, The Euro-Crisis and the Courts: Judicial Review and the Political Process in Comparative Perspective, 32 BERKELEY J. INT'L L. 64, 117-18 (2014).

19. See European Council Conclusions EUCO 104/2/13 of 28 June 2013, at 1 (launching an initiative to fight youth unemployment).

20. See Federico Fabbrini, States' Equality v States' Power: The Euro-crisis, Inter-state Relations and the Paradox of Domination, 17 CAMBRIDGE Y.B. EUR. LEGAL STUD. 1, 1 (2015). 
originally been designed to strike a delicate balance between states' power and states' equality, the Euro-crisis and the responses to it have increasingly upset this balance, empowering bigger, economically stronger member states to the detriment of smaller, economically weaker ones. Legal reforms in salient areas such as economic assistance, financial stabilization, and banking resolution have formally entrenched the asymmetry of power between the member states, recognizing special privileges for some of them and enshrining into law their preferred economic policy. ${ }^{21}$ Moreover, as both lawyers and political scientists have emphasized, a growing imbalance between the member states has also emerged in the European Union's decisionmaking process. ${ }^{22}$

In particular, the European Council has emerged as the "new centre of EU politics," ${ }^{23}$ as far as economic policy is concerned. ${ }^{24}$ Within this intergovernmental body, however, larger member states have been able to play a dominant role at the expense of the other members. As Jonas Tallberg has emphasized, bargaining in the European Council is the result of several sources of power: state sources of power, institutional sources of power, and personal sources of power. ${ }^{25}$ Although, formally speaking, all heads of state or government enjoy equal status in the European Council-every state having one representative that can authoritatively represent the view of its country-in reality "differences between large and small Member states" shape power relations in the European Council. ${ }^{26}$ Aggregate state sources of power play the most fundamental role in explaining negotiation in the European Council, with the result that larger member states can dominate the process. ${ }^{27}$ In

21. See id.

22. See generally Mark Dawson \& Floris de Witte, Constitutional Balance in the EU after the Euro-Crisis, 76 MOD. L. REV. 817 (2013) (analyzing reforms undermining the constitutional balance and affecting stability in the EU context); Georgios Maris \& Pantelis Sklias, Intergovernmentalism and the New Framework of EMU Governance, in WHAT FORM OF GOVERNMENT FOR THE EUROPEAN UNION AND THE EUROZONE? 57 (Federico Fabbrini et al. eds., 2015).

23. Uwe Puetter, The European Council-the New Centre of EU Politics, 16 SwED. INST. EUR. POL'Y, EUR. POL'Y ANALYSIS 1 (2013).

24. See infra Part II.

25. Jonas Tallberg, Bargaining Power in the European Council, 46 J. CoMmoN MKT. STUD. 685, 687 (2008).

26. Id.

27. In another intergovernmental context, that of the Eurogroup-which brings together the finance ministers of the Eurozone member states, under the chairmanship of a semi-permanent presidency-the former President of the Eurogroup Jean-Claude Juncker famously decided to step down from the job complaining that it was impossible for him to make decisions because of the way Germany and France were running the show. See Patrick Henry \& Brian Parkin, Juncker Says Ceding Euro Job Due to Franco-German 
this context, it is not surprising that Germany has come to play a hegemonic role in defining the economic agenda of the European Union. ${ }^{28}$ Since reunification, Germany has been the most populous EU member state. ${ }^{29}$ At the same time, thanks to the major economic reforms the center-left Schröder Government undertaken between 1998 and 2005, Germany found itself in the healthiest economic condition of any EU member state when the Euro-crisis erupted. ${ }^{30}$

The policy of austerity that ensued in the European Union largely tracked German preferences. ${ }^{31}$ On one hand, promotion of austerity at the EU level reflected the export of long-term German economic ideas across the European Union. ${ }^{32}$ Christian Joerges has underlined how the logic of austerity has strong roots in the ordoliberal theory that has underpinned German economic policy since World War II. ${ }^{33}$ According to this view-that has now been also constitutionalized in the Basic

Interference, BLOOMBERG (Apr. 30, 2012, 2:45 PM), http://www.bloomberg.com/news/ articles/2012-04-30/juncker-says-ceding-euro-job-due-to-franco-german-interference

(reporting Mr. Juncker as stating that Germany and France acted in the Eurogroup "as if they are the only members of the group").

28. See William E. Paterson, The Reluctant Hegemon? Germany Moves Centre Stage in the European Union, 49 J. COMMON MKT. STUD. 57, 73 (2011).

29. See Population, EUROSTAT, http://epp.eurostat.ec.europa.eu/tgm/table.do?tab= table\&language $=$ en\&pcode $=$ tps $00001 \&$ tableSelection $=1 \&$ footnotes $=$ yes\&labeling=labels\& plugin=1 (last visited Aug. 7, 2014).

30. See Gerhard Schröder, Fed. C. Ger., Courage for Peace and Courage for Change, Policy Statement at the German Bundestag (Mar. 14, 2003) (outlining the famous Agenda 2010); See also A Quick Guide To 'Agenda 2010', DEUTSCHE Welle (Oct. 17, 2003), $\mathrm{http} / / / \mathrm{www}$.dw.de/a-quick-guide-to-agenda-2010/a-988374-1, for an overview in English of the measures adopted by the Schröder Government.

31. The argument advanced here should not be taken to mean that all German economic preferences have been incorporated into EU economic policy. A good example is the proposal for "contractual arrangements," which aimed to bind EU member states in fragile economic conditions to a detailed program of structural reforms in exchange for financial assistance by wealthier member states. Germany strongly pushed for this proposal-and the European Commission followed up on it. See Communication from the Commission to the European Parliament and the Council-The Introduction of a Convergence and Competitiveness Instrument, COM(2013) 165 final (Mar. 20, 2013). However, opposition by virtually every other EU member state made the proposal moot. See Press Release, Gov't of the Neth., Contractual Arrangements with EU Member States not Binding, says Rutte (Dec. 20, 2013), available at http://www.government.nl/news/ 2013/12/20/contractual-arrangements-with-eu-member-states-not-binding-says-rutte.html (reporting opinion of Dutch Prime Minister Mark Rutte against binding contractual arrangements imposed by the EU).

32. See generally David J. Gerber, Constitutionalizing the Economy: German NeoLiberalism, Competition Law and the "New" Europe, 42 AM. J. CoMP. L. 25 (1994).

33. See Christian Joerges, Europe's Economic Constitution in Crisis and the Emergence of a New Constitutional Constellation, 15 GERM. L.J. 985, 989 (2014). 
Law ${ }^{34-t h e}$ government should run a sound fiscal policy, with a balanced budget and a prohibition on contracting public debt. At the same time, the German economy had been traditionally characterized as export-oriented and based on the capacity of labor-management relations to contain pressures for salary increases as a condition to boost competitiveness. $^{35}$ Following the outbreak of the crisis, Germany prescribed the ordoliberal receipt throughout the European Unionpromoting the constitutionalization of budgetary constraints in the EU member states via the Fiscal Compact, ${ }^{36}$ and advocating fiscal consolidation and structural reforms as a way to increase competitiveness and growth in the Eurozone. ${ }^{37}$

On the other hand, the promotion of austerity to respond to the Euro-crisis also represented the most apt strategy for Germany to promote its contingent interests in the European Union. The design of tough economic adjustment programs for countries receiving financial assistance was, in fact, the best policy option to protect German banking interests. ${ }^{38}$ Despite the rhetoric to the contrary, the choice to bail out EU member states in fiscal trouble, such as Greece, was an alternative to sovereign default. ${ }^{39}$ Article 125 of the Treaty on the Functioning of the European Union (TFEU) enshrined a no-bail-out clause. ${ }^{40}$ Yet the Greek bail-out was the option that better protected the interests of German (and French) banks, shielding them from financial losses, while shifting the costs of the rescue to the assisted country. ${ }^{41}$ Greece was

34. Gesetz zue Änderung des Grundgesetzes [Law Amending the Basic Law], July 29, 2009, BGBL. I S. at 2248 (Ger.).

35. See Germanys Economic Model: What Germany Offers the World, ECONOMIST, Apr. 14, 2012, http://www.economist.com/node/21552567.

36. See generally THE Constitutionalization of EUROPEAN Budgetary ConstraINTS (Federico Fabbrini et al. eds., 2014) (describing the constitutional incorporation of the "golden rule" by the EU member states).

37. See, e.g., Angela Merkel, Fed. C. Ger., Government Statement Delivered by Chancellor Angela Merkel on the EU's Eastern Partnership Summit (Nov. 18, 2013) (calling EU member states to implement economic reforms).

38. See Helen Thompson, The Crisis of the Euro: The Problem of German Power Revisited, Sheffield POliTICAL ECON. RESEARCh INST. PAPER No. 8 (Univ. of Sheffield, Sheffield, U.K.), Dec. 2013, at 7.

39. See Mark Blyth, AUSTerity: The History of A DANGerous IdEA 98 (2013) (criticizing the justification of the responses to the crisis based on the argument that "there is no alternative").

40. See Jean-Victor Louis, Guest Editorial, The No-Bailout and Rescue Packages, 47 COMMON MKT. L. REV. 971, 976 (2010).

41. I do not have sufficient knowledge to judge whether Greek sovereign debt default would have been a better option for Greece, although I am persuaded that it could have been extremely dangerous for the Eurozone as such. See Lorenzo Bini Smaghi, Member of the Exec. Bd. of the Eur. Cent. Bank, Speech on "Monetary and Financial Stability in the Euro Area" at the State of the Union Conference (May 10, 2011) (explaining that default 
subject to a tough program of economic adjustment as a condition for receiving financial aid, which involved heavy cuts to the welfare state to repay its loans-and the interest rates-to countries lending money. ${ }^{42}$ Otherwise, it is worth remembering that, despite Germany's current obsession with governments' deficit, Germany was the first EU member state, together with France, to violate the deficit rule set in the EU Stability and Growth Pact (SGP) ${ }^{43}$ when doing so suited its economic interest. ${ }^{44}$ Promoting austerity in the European Union in response to the Euro-crisis was therefore also a deliberate policy choice by the German government.

Given Germany's centrality in setting EU economic policy, political protest and electoral change in other EU member states have only marginally altered the pro-austerity stance of the European Union. ${ }^{45}$ It is true that other, smaller member states of Northern Europe-such as Finland-endorsed a policy of austerity. ${ }^{46}$ However, the ways in which Germany led the decision-making process on austerity were perceived as problematic even in this country, due to the increasing marginalization of the national democratic arena. ${ }^{47}$ At the same time,

or debt restructuring is a dramatic economic and social event for the country which experiences it, which leads many into poverty).

42. See Xenophon Contiades \& Ioannis A. Tassopoulos, The Impact of the Financial Crisis on the Greek Constitution, in CONSTITUTIONS IN THE GLOBAL FINANCIAL CRISIS 195 (Xenophon Contiades ed., 2013).

43. See generally, Consolidated Version of the Treaty on European Union-Protocol No. 12 on the Excessive Deficit Procedure, art. 1, 2010 O.J. (C 83) 279 (stating that member states must run yearly deficits of below 3\% of GDP and that they must have a public debt of below $60 \%$ of GDP).

44. See Council Decision 2003/89/EC, on the existence of deficit in Germany 2003 O.J. (L 34) 16 (holding sanctions against Germany in abeyance). But see, Case C-27/04, Comm'n v. Council, 2004 E.C.R. I-6649 (EU Court of Justice recognizing wide discretion to the Council whether to impose sanctions under the SGP as recommended by the Commission, or held in abeyance the excessive deficit procedure against Germany and France).

45. See also ANDrew Glencross, The Politics of EuRopean InTEGRATION 305 (2014) (stating that "in a new departure for integration, it was one country in particular that set the agenda. Germany, the economic powerhouse of the Eurozone and the biggest contributor to bailout packages, played a central role in determining that indebted countries would need to implement austerity.").

46. See, e.g., Korkein hallinto-oikeus [KHO] [Supreme Administrative Court] May 14, 2013, 2013:90 (Fin.) (Finnish Supreme Administrative Court ordering the publication of the deal between the Finnish Minister of Finance and the Greek counterpart to obtain collateral as a conditions to grant financial aid to Greece, which was largely seen as imposing austerity).

47. See generally Päivi Leino \& Janne Salminen, The Euro Crisis and its Constitutional Consequences for Finland: Is There Room for National Politics in EU Decision-Making?, 9 EUR. CONST. L. REV. 451 (2013) (detailing Finland's skeptical response to recent EMU developments, especially concerning democratic decisionmaking). 
although it has been suggested that austerity was welcomed by some national elites in Southern Europe-for example in Italy or Greece, which conveniently put the blame on Germany to pass domestic reforms which could not otherwise have been adopted ${ }^{48}$-technocratic governments were eventually ousted by politicians elected on platforms that explicitly opposed austerity. ${ }^{49}$ Yet, the election of anti-austerity parties in these countries did not produce changes to EU policies, suggesting that as long as Germany remains committed to a policy of austerity, it is unlikely that any economic change will be foreseeable in the European Union. ${ }^{50}$

The case of Greece, of course, epitomizes this state of affairs. The tough austerity policy that the technocratic government of Lucas Papademos and the center-right government of Antonis Samaras implemented as a condition for financial assistance by European and international creditors had a huge impact on Greek society, ${ }^{51}$ shrinking domestic economic output by 25 percent between 2011 and $2014 .^{52}$ In reaction to this, the snap elections in January 2015 swept an antiausterity coalition led by the leftist party Syriza into power with a clear mandate to renegotiate the conditions set in the bailout and to remedy the humanitarian crisis shaking the nation. ${ }^{53}$ However, the new Greek government was quickly forced to bow to the pressures of its European partners. ${ }^{54}$ In February 2015, after tense negotiations-especially with

48. See Susannah Verney \& Anna Bosco, Living Parallel Lives: Italy and Greece in an Age of Austerity, 18 S. EUR. SOC'Y \& POL. 397, 421 (2014) (discussing action by technocratic governments in Italy and Greece).

49. See Hauke Brunkhorst, Collective Bonapartism - Democracy in the European Crisis, 15 GER. L.J. 1177, 1179 (2014).

50. See A Teutonic Union, ECONOMIST, Sept. 13, 2014, http://www.economist.com/ news/europe/21616954-behind-scenes-germany-quietly-asserts-its-influence-brusselsteutonic-union (stating that "the euro crisis has shifted power decisively to Angela Merkel's Germany" and arguing that this power has now been entrenched).

51. See Philippe Legrain, Op-Ed, Euro-Zone Fiscal Colonialism, N.Y. Times, Apr. 21, 2014, http:/www.nytimes.com/2014/04/22/opinion/euro-zone-fiscal-colonialism.html?_r=0 (arguing that management of the Euro-crisis has created "quasi-colonial relationship" between EU member states).

52. See U.S. DeP'T OF STATE, 2014 Investment Climate Statement - Greece 1 (June 2014), http://www.state.gov/documents/organization/229022.pdf (reporting 25\% contraction of Greek GDP).

53. See Patrick Donahue, Tsipras Win Draws French Congratulations, German Theat, EKATHIMERINI (Jan. 26, 2015), http://www.ekathimerini.com/4dcgi/_w_articles_ wsite1_1_26/01/2015_546536.

54. See also Federico Fabbrini, The Greek Crisis and the Need for Constitutional Reform in the Eurozone, VERFASSUNGSBLOG (Mar. 21, 2015), http://www.verfassungsblog.de/ making-elections-matter-again-the-greek-crisis-and-the-need-for-constitutional-reformsin-the-eurozone/\#.VTKI5a3BzGc (discussing negotiations between Greece and its creditors). 
the German Finance Minister Wolfgang Schäuble-and facing a likely financial shortfall, the Greek Finance Minister Yanis Varoufakis had to concede that its government would not roll back on the previously agreed-to reform plans, and would implement domestically its electoral promises only if doing so had "no negative fiscal effect."55

The case of France and Italy-the second and third largest Eurozone member states-also offers a striking snapshot of that reality. Although François Hollande campaigned in 2012 on a platform that advocated repeal of the Fiscal Compact and a strategy to promote growth and tackle unemployment, ${ }^{56}$ once he became the president of France he was forced to backtrack on his promises. Leading a country weakened by increasing economic difficulties, ${ }^{57}$ President Hollande had to cultivate special relations with Germany to keep France afloat and ended up implementing the German economic blueprint ${ }^{58}$ _-extracting in exchange only a largely symbolic, and non-legally binding, Compact for Growth and Jobs. ${ }^{59}$ In fact, when in August 2014 the French Minister of the Economy, a prominent member of the left wing of the Socialist Party, openly criticized the German-led policy of austerity, the French President removed him, suggesting that in the intergovernmental framework of the European Council, France is in no condition to challenge the position of Germany. ${ }^{60}$

Similarly, the electoral victory of Italy's Democratic Party in 2013 on an anti-austerity platform did not produce visible change in EU

55. Letter from Yanis Varoufakis, Fin. Minister of Greece, to Jeroen Dijsselbloem, President of the Eurogroup (Feb. 24, 2015), available at http://www.reuters.com/ article/2015/02/24/us-eurozone-greece-text-idUSKBNOLS0V520150224.

56. See Steven Erlanger \& Nicholas Kulish, French Front-Runner Says He'd Seek to Renegotiate Fiscal Treaty if Elected, N.Y. TIMES, Apr. 25, 2012, http://www.nytimes.com/ 2012/04/26/world/europe/hollande-says-hell-seek-new-fiscal-treaty-if-elected-in-

france.html?_r=0.

57. See also the report to the French Prime Minister by the Commission chaired by Louis Gallois (the so-called Rapport Gallois), Louis Gallois, Pacte Pour La Compétitivité De L'industrie Française (Nov. 5, 2012), for a discussion of the weak state of France's economy and a proposal for a competiveness pact for industry.

58. See e.g., Loi 2012-1403 du 17 décembre 2012 relative à la programmation et à la gouvernance des finances publiques [Law 2012-1403 of December 17, 2012 on the programming and governance of public finances], JOURNAL OFFICIEL DE LA REPUBLIQUE FranÇaISE [J.O.] [OFficial GaZetTe of FranCE], Dec. 18, 2012, p. 19816. (Fr.) (incorporating the Fiscal Compact in France).

59. See European Council Conclusions EUCO 76/12 of 29 June 2012, Annex.

60. See Liz Alderman \& Dan Bilefsky, New French Cabinet Sheds Critics and Leaves Austerity Policies in Place, N.Y. TIMES, Aug. 26, 2014, http://www.nytimes.com/ 2014/08/27/world/europe/france-new-government.html?_r=0 (reporting decision by the French President to charge the Prime Minister to form a new cabinet ousting the former French Minister of the Economy Arnaud Montebourg, a prominent leftist, who had openly criticized Germany for imposing austerity policy on the other EU member states). 
economic policy. Because of a number of weaknesses in its domestic institutional system, Italy has traditionally been characterized by unstable executives and has thus been able to wield only limited influence in EU intergovernmental fora. ${ }^{61}$ Things have changed in 2014 with the appointment of Matteo Renzi's government, which has embraced a more assertive role in EU policy making, not least because Italy happened to hold the rotating six-month presidency of the Council of the European Union 62 in the second half of $2014 .^{63}$ Nevertheless, Italy also suffers long-standing structural economic problems, notably a public debt that for decades has ranked as one of the highest in the Eurozone. ${ }^{64}$ These economic weaknesses have so far prevented Italy from effectively rebalancing power in the European Council and pushing for an alternative economic agenda at the EU level. ${ }^{65}$

In conclusion, Europe has embraced austerity policy as a way to respond to the crisis. The prevailing narrative since 2009 considered irresponsible state fiscal behavior the main cause of the crisis. Unsurprisingly, therefore, policy makers advocated budget cuts and fiscal consolidation as the main strategy to address the crisis and restore economic confidence. Yet, despite the increasing discontent for austerity, this policy has remained resilient over the years. The explanation of this entrenchment has to do with the evolving relations between the EU member states and the growing centrality that Germany-the largest EU member state and its economic powerhousehas come to play in EU decision making. The promotion of austerity largely tracked German preferences-not only its long-term, ordoliberal conception of economic governance, but also its short-term interests in protecting the domestic banking sector. At the same time, because of the disproportionate influence wielded by Germany within the EU

61. See Tallberg, supra note 25 , at 690 .

62. See TEU, supra note 3 , art. 16(9) (stating that the presidency of the Council shall be held by every member state on the basis of equal rotation).

63. See generally 2014 ITALIAN PRESIDENCY COUNCIL EUR. UNION, http://italia2014.eu/en/ (last visited Nov. 20, 2014).

64. See Government Debt Increased to $93.9 \%$ of GDP in Euro Area and to $88.0 \%$ in EU28, EuRostat NeWS RELEASE EuRoINDICATORS, July 22, 2014, available at http://ec.europa.eu/eurostat/documents/2995521/5175186/2-22072014-AP-EN.PDF/

86c55faa-ea8c-42f9-b9cb-e0d1be68e957 (reporting Italy's debt to GDP ratio as the second highest in the EU after Greece).

65. But see Communication from the Commission to the European Parliament, the Council, the European Central Bank, the Economic and Social Committee, the Committee of the Regions and the European Investment Bank, Making the Best Use of the Flexibility within the Existing Rules of the Stability and Growth Pact, COM (2015) 12 final (Jan. 13, 2015) (recognizing the importance of a flexible application of the existing rules of the SGP to account for a downswing in the economic conditions of EU member states as repeatedly advocated by the Italian government). 
intergovernmental decision-making fora, no electoral result at the national level has substantially affected the direction of EU economic policy.

\section{INTERINSTITUTIONAL CHANGE AND EU ECONOMIC GOVERNANCE}

If the resilience of austerity has revealed a growing imbalance of powers among the EU member states, the definition of economic policy in the European Union during the Euro-crisis also reflects a deeper interinstitutional development in the architecture of the European Union. Whereas the predominance of austerity policy under the influence of Germany may be contingent, and subject to future changes, ${ }^{66}$ the events unleashed by the Euro-crisis have highlighted how the European Council has structurally become the central institution in setting the economic agenda of the European Union. Although the European Council had historically played an important role at key moments in the history of European integration, ${ }^{67}$ its role used to be subsidiary. In fact, until the Lisbon Treaty entered into force in 2009, the European Council was not recognized as an official institution of the European Union. ${ }^{68}$ Since the eruption of the crisis, the European Council has moved to the forefront, becoming an institution regularly involved in deciding the agenda of the European Union and its member states. ${ }^{69}$ In the field of economic governance, in particular, the European Council has become the leading EU institution, and "economic governance occupies $50-65 \%$ of the total time the heads [of state and government] spend debating within the European Council."70

Although some observers may suggest that the rise of the European Council is only a temporary evolution triggered by exceptional circumstances such as the Euro-crisis, as Uwe Puetter has argued, the centrality of the European Council in the field of economic governance is

66. It should be remembered that in the late 1990s Germany was regarded as the "sick man of the Euro" and played a much more limited role in EU policy making. See The Sick Man of the Euro, ECONOMIST, June 3, 1999, available at http://www.economist.com/ node/209559 (emphasizing German economic stagnation in the decade following reunification).

67. See generally LuUK VAN MiddelaAR, The Passage to Europe: How a ConTINENT BECAME A UNION (Liz Waters trans., 2013) (2009).

68. See Editorial Comments, An Ever Mighty European Council - Some Recent Institutional Developments, 46 COMM. MKT. L. REV. 1383, 1385 (2009).

69. See generally Frederic Eggermont, The Changing Role of the European COUNCIL IN THE INSTITUTIONAL FRAMEWORK OF THE EUROPEAN UNION (2012) (describing the formation of the European Council).

70. Puetter, supra note 23, at 7 . 
not a haphazard development.71 Rather, the European Council's central role is the result of a deliberate institutional choice made at the time of the Maastricht Treaty of 1992 and has only become fully noticeable today. ${ }^{72}$ When creating the EMU, the EU member states established a supranational authority-the European Central Bank (ECB)-to manage the monetary pillar of the EMU73 but refrained from introducing a full-fledged communitarization of economic policy. ${ }^{74}$ Instead, the economic pillar of the EMU has since the beginning been characterized by the coordination of the economic policies of the EU member states, which was to be accomplished through an intergovernmental framework designed to foster deliberation and consensus-building between them. ${ }^{75}$ According to Puetter, this is the paradox of integration in post-Maastricht Europe: "while policy interdependencies have grown, member state governments have resisted the further transfer of formal competences to the EU level and did not follow the model of the Community method."76

In the EMU, the power to set the economic agenda is entrusted to the European Council-as well as to the Economic and Financial Affairs (ECOFIN) Council, which groups the finance ministers of the EU member states, and to the Eurogroup, which brings together the finance ministers of the Eurozone countries. ${ }^{77}$ This has important implications for interinstitutional balance. ${ }^{78}$ In particular, the European Commission, which had traditionally been-and still is-the engine of integration in policies such as agriculture, competition, and the internal market, plays a more limited role in the field of economic policy.79 Certainly, the Commission remains a key player in the institutional architecture of the European Union; it enjoys the formal monopoly of legislative initiative, is endowed of a large bureaucracy, and has

71. Uwe Puetter, The European Council and the Council: New INTERGOVERNMENTALISM AND INSTITUTIONAL CHANGE 68 (2014).

72. See id. at 68-69; Treaty on European Union, Feb. 7, 1992, 1992 O.J. (C 191).

73. See generally ChIARA ZILIOLI \& MARTIN SELMAYR, THE LAW OF THE EUROPEAN CENTRAL BANK (2001) (explaining the establishment of the European Monetary Union).

74. PUETTER, supra note 71 , at 17.

75. Id. at 59 .

76. Uwe Puetter, Europe's Deliberative Intergovernmentalism: The Role of the Council and European Council in EU Economic Governance, 19 J. EUR. PUB. PoL. 161, 161 (2002).

77. See generally Uwe Puetter, The Eurogroup: How a Secretive Circle of Finance Ministers Shape European ECONOMic Governance (2006) (explaining the Eurogroup).

78. Youri Devuyst, The European Union's Institutional Balance after the Treaty of Lisbon: "Community Method" and "Democratic Deficit" Reassessed, 39 GEO. J. INT'L L. 247, 314 (2008).

79. PUETTER, supra note 71, at 230. 
enforcement power vis-à-vis the member states. ${ }^{80}$ As Paul Craig has explained, in response to the crisis, the Commission has had a significant role in pushing through legislative reforms to the architecture of economic governance in the European Union. ${ }^{81}$ Moreover, the Commission has acquired new powers to police the budgetary policy of the member states. ${ }^{82}$ In fact, the Commission has been very diligent in forcing the member states to abide by the austerity policy set at the European level. ${ }^{83}$

Nevertheless, the Commission's ability to define the economic agenda of the European Union is largely dependent on the European Council. ${ }^{84}$ As it appeared during the Euro-crisis, the Commission was mainly tasked with implementing decisions made by the European Council. ${ }^{85}$ In fact, the legislative reforms of the architecture of the EMU-the so-called "six pack" and "two pack" sets of regulations and directives reforming the SGP-were dictated by the European Council on the basis of the report on "Strengthening Economic Governance in Europe," ${ }^{86}$ which was prepared by the President of the European

80. See Renaud Dehousse \& Laurie Boussaguet, L'impact de la crise sur la gouvernance européenne, 149 PouvoIRs 7 (2014).

81. Paul Craig, The Financial Crisis, the EU Institutional Order and Constitutional Responsibility, in WHAT FORM OF GOVERNMENT FOR THE EUROPEAN UNION AND THE EUROZONE? 17 (Federico Fabbrini et al. eds., 2015).

82. Roland Bieber, Observer - Policeman - Pilot?: On Lacunae of Legitimacy and the Contradictions of Financial Crisis Management in the European Union 9 (EUI Law Dep't Working Paper No. 16, 2011).

83. The role of Mr. Olli Rehn, the former European Commissioner for Economic and Monetary Affairs and the Euro, in promoting austerity policies has been particularly emphasized. See Maroun Labaki \& Beatrice Delvaux, Moi, Olli Rehn, au service de l'Europe et des Européens, LE SoIR, Feb. 25, 2014 (reporting Mr. Olli Rehn's, the former European Commissioner for Economic and Monetary Affairs and the Euro, role in promoting austerity policy and the confrontation between Mr. Rehn and Mr. Paul Magnette, the President of the Belgian Socialist Party); see also Commission Report, European Commission 2010-2014 A Record of Achievements, at 24 (Apr. 2014), available at http://ec.europa.eu/archives/commission_2010-2014/president/achievements/files/RoA_EN.pdf (reporting Rehn's view that his work at the European Commission had contributed to "protect financial stability and restore fiscal and economic credibility").

84. See generally Dermont Hodson \& Uwe Puetter, The European Union and the Economic Crisis, in EUROPEAN UNION Politics 367 (Michelle Cini \& Nieves PérezSolórzano Borragán eds., 4th ed. 2013) (explaining the role of the Commission in fiscal policy).

85. See generally European Parliamentary Research Service, European Council Conclusions: A Rolling Check-List of Commitments to Date, PE 536.361 (Nov. 14, 2014) (reporting the growing list of actions that the European Council tasks the Commission to carry forward).

86. See Report of the Task Force of the European Council on Strengthening Economic Governance in the EU, at 1-4 (Oct. 21, 2010), available at https://www.consilium.europa.eu/ uedocs/cms_data/docs/pressdata/en/ec/117236.pdf (identifying five pillars for reform, 
Council in October 2010 and steered by the Economic and Financial Committee (EFC)- the powerful intergovernmental body that prepares the work of the ECOFIN Council. ${ }^{87}$ Equally, it was the European Council that designed the architecture of the programs of financial rescue with related conditionality, which the Commission then executed jointly with the ECB and the IMF. 88

Interestingly enough, the centrality of the European Council in EU economic policy has not been altered by the recent push to connect the appointment of the European Commission to the election of the European Parliament.89 At the May 2014 European Parliament elections, the European political parties decided to advance lead candidates for the position of President of the European Commission, claiming that the candidate of the European party that would win the European Parliament elections ought to become the President of the Commission. ${ }^{90}$ This initiative was grounded in the new Article 17(7) of the TEU, as modified by the Lisbon Treaty of 2009, which states that the European Council shall appoint the President of the European Commission "[t]aking into account [the results of] the elections to the European Parliament." Following this procedure, Jean-Claude Juncker, the Spitzenkandidat (top candidate) ${ }^{91}$ of the conservative European Peoples' Party (which came in as the party with a plurality of 29.4 percent of seats), ${ }^{92}$ was nominated European Commission President by

namely: (1) greater fiscal discipline; (2) broader economic surveillance; (3) deeper economic coordination via the European Semester; (4) more robust framework for crisis management; and (5) stronger institutions for more effective economic governance).

87. PUETTER, supra note 71, at 117-18.

88. Michael Schwartz, A Memorandum of Misunderstanding - The Doomed Road of the European Stability Mechanism and a Possible Way Out: Enhanced Cooperation, 51 COMMON MKT. L. REV. 389, 390-97 (2014).

89. See Daniel Kelemen \& Anan Menon, Fight Club: When the EU's Campaign Season Ends, the Real Political Battles Will Begin, ForeIGN AFFAIRS, May 18, 2014 (anticipating continuing centrality of the European Council after the elections for the European Parliament).

90. Commission Recommendation on Enhancing the Democratic and Efficient Conduct of the Election to the European Parliament, at 4, COM (2013) 1303 final (Mar. 12, 2013).

91. Editorial Comments, After the European Elections: Parliamentary Games and Gambles, 51 COMMON MKT. L. REV. 1047, 1048 (2014) (discussing the political origin of the process of the leading candidates and arguing that "[s]omewhat tellingly, and indicating a certain unwillingness to embrace the concept in other Member States, the candidates have become known under their German name Spitzenkandidaten throughout the EU'). See also infra note 98 (discussing influence of the German constitutional mindset over the emergence of this new procedure for selecting the possible President of the European Commission).

92. Result of the 2014 European Elections, EUROPEAN PARLIAMENT (July 1, 2014, 10:14 AM), http://www.results-elections2014.eu/en/election-results-2014.html. 
the European Council in June 2014, ${ }^{93}$ and confirmed in the post by a vote of the Parliament's plenary in July 2014. ${ }^{94}$ President-elect Juncker then negotiated with the EU member states represented in the Council a list of Commissioners (one per member state), ${ }^{95}$ who were vetted through hearings by the European Parliament and eventually confirmed by the European Parliament as the new College of Commissioners in October 2014.96

The election of the new European Parliament, and the decision by the political parties to bring forward lead candidates to the post of Commission President, attracted increasing attention in the European Union. ${ }^{97}$ A growing number of scholars and opinion makers hailed the event as the institutional evolution of the European Union toward a parliamentary system of government, akin to the German model, ${ }^{98}$ with the injection of electoral competition for the choice of who should run the European Union and in which direction. ${ }^{99}$ According to some accounts, the election would also craft a space for contestation between the Left and the Right, and thus create the conditions for a change in economic policy, moving away from austerity and focusing more on growth. ${ }^{100}$

93. European Council Conclusions EUCO 79/14 of 27 June 2014 (proposing the appointment of Jean-Claude Juncker with twenty-six heads of state and government in favor, and two against).

94. See Press Release, European Parliament, Parliament Elects Jean-Claude Juncker as Commission President (July 15, 2014) (reporting vote to elect Jean-Claude Juncker as Commission President with 422 votes in favor, 250 against, and 47 abstained).

95. See Press Release, Council of the European Union, Council Adopts New List of Commissioners-Candidates (Oct. 15, 2014) (reporting the final list of Commissionerscandidates designated by the Council, in common accord with President-elect Juncker, following the resignation of one of the previous candidates in light of her negative performance during the parliamentary hearings).

96. See Press Release, European Parliament, Parliament Elects New European Commission (Oct. 22, 2014) (reporting vote to approve the new College of Commissioners with 423 votes in favor, 209 against, and 67 abstentions).

97. See, e.g., Joseph H.H. Weiler, Editorial, European Parliament Elections 2014: Europe's Fateful Choices, 24 EUR. J. INT'L L. 747 (2013) (explaining issues at stake in the election).

98. See Mattias Kumm, What Kind of a Constitutional Crisis Is Europe in and What Should Be Done About It? 18 (Wissenschaftszentrum Berlin für Sozialforschung [WZB] Discussion Paper No. 801, 2013) (showing German support and influence for the idea of parliamentarizing the EU).

99. See, e.g., Marcelino OREja Et Al., Proposals for the Future of Europe: The ROAD TO AN ECONOMIC AND POLITICAL UNION 19 (2014).

100. See, e.g., Simon Hix \& Christoph Crombez, Why the European Parliament Elections Will Be About More Than Protest Votes, LONDON ScHOOL ECONOMICs BLOG (June 3, 2013), http://blogs.lse.ac.UK/europpblog/2013/06/03/european-parliament-elections-2014/ (stating that European elections will determine whether or not austerity remains the EU policy to address the Euro-crisis). 
However, this did not happen. On the one hand, the appointment of the President of the Commission following the Spitzenkandidaten process did not deprive the member states of the privilege of nominating the other Commissioners, with the result that the College of Commissioners is not a homogenous political body, but rather a patchwork of national interests, reflecting heterogeneous political positions. ${ }^{101}$ On the other hand, the European Council crucially reaffirmed its centrality in defining the economic agenda of the European Union despite steps toward the parliamentarization of the relationship between the European Parliament and the Commission. In the same summit in which it decided to nominate Jean-Claude Juncker as President of the European Commission, the European Council unveiled a detailed program, which it tasked the new Commission to carry forward. In a document called "Strategic Agenda for the Union in Times of Changes," 102 the European Council outlined the policy priority for the European Union in the next five years and tasked the future European Commission to implement it. ${ }^{103}$ As far as economic policy is concerned, the European Council mentioned the plague of unemployment and emphasized its commitment toward "stronger economic policy coordination, convergence and solidarity."104 Nevertheless, the European Council reaffirmed the importance of respecting the SGP, of pursuing structural reforms, and of encouraging competitiveness ${ }^{105}$ - thus suggesting a continuation of the policies so far followed to address the crisis.

In fact, in its subsequent meetings since the appointment of the new European Commission, the European Council has continued to set the economic direction of the European Union, using its "conclusions" as "an instrument for exercising leadership." 106 Hence, in October 2014 the European Council reaffirmed "the urgency of the prompt implementation of measures to boost jobs, growth, competitiveness and

101. See also John Peterson, The College of Commissioners, in THE INSTITUTIONS OF THE EUROPEAN UNION 96, 112 (John Peterson \& Michael Shackleton eds., 3rd ed. 2012).

102. European Council Conclusions, supra note 93, at Annex 1.

103. European Commission President Juncker himself took notice of this Strategic Agenda when delivering his speech in front of the European Parliament to obtain its vote of approval. See Jean-Claude Juncker, Candidate President Eur. Comm'n, Speech at the European Parliament: "A New Start for Europe: My Agenda for Jobs, Growth and Democratic Change" (July 15, 2014) (outlining his political agenda but acknowledging that he will also "draw on the 'Strategic Agenda for the Union in Times of Change', as adopted by the European Council . . . and on the orientations that will be given by the European Parliament in the months to come.").

104. European Council Conclusions, supra note 93, at 16.

105. Id. at 15.

106. PUETTER, supra note 71 , at 134. 
of those aimed at empowering and protecting its citizens as set out in the Strategic Agenda for the Union in Times of Change."107 And in December 2014, the European Council called for setting up the European Fund for Strategic Investments (EFSI) and invited the Parliament and the Council to pass appropriate legislation within six months, while introducing some caveats on the use of the fund. ${ }^{108}$ The proposal to establish the EFSI, aimed at mobilizing $€ 315$ billion to kickstart investment in the European Union, constituted the flagship initiative of the new European Commission. ${ }^{109}$ But it is significant that in unveiling its investment plan in November 2014, the Commission explicitly asked the European Council to endorse its initiative110_even though this was not formally needed-confirming that also in the perception of the Commission itself it is the European Council that holds the keys for the adoption of any new major economic policy measure in the European Union.

In conclusion, the resilience of austerity policies in response to the Euro-crisis has brought to the surface an important underground institutional evolution within the European Union. In defining the strategy to respond to the crisis, the European Council has emerged as the leading institution in setting EU economic policy. As Uwe Puetter has explained, however, this institutional development finds its roots in the post-Maastricht integration paradox, in which member states agreed to coordinate their economic policies at the EU level but not to entrust new tasks to supranational authorities. ${ }^{111}$ The new intergovernmentalism in the field of economic governance has significantly reduced the traditional role of the European Commission. In fact, not even the changes produced by associating the appointment of the European Commission President with the elections for the European Parliament have deprived the European Council of the power to set the EU agenda in the field of economic policy. Regardless of the

107. European Council Conclusions EUCO 169/14 of 24 October 2014, 10.

108. European Council Conclusions EUCO 237/14 of 18 December 2014, 1-3.

109. See Communication From the Commission to the European Parliament, the Council, the European Economic and Social Committee and the Committee of the Regions, Commission Work Programme 2015: A New Start, at 4, COM (2014) 910 final (Dec. 16, 2014) (emphasizing priority importance of EFSI in the Commission work program).

110. See Communication From the Commission to the European Parliament, the Council, the European Economic and Social Committee and the Committee of the Regions, An Investment Plan for Europe, at 6, COM (2014) 903 final (Nov. 26, 2014) (stating that "[t]he European Council is invited to endorse the setting up of the [EFSI]"); id. at 13 (stating that "[t]he European Council is invited to endorse the overall approach"); $i d$. at 16 (stating that "[t]he Commission invites the European Council . . . to endorse the Plan with all its strands").

111. PUETTER, supra note 71 , at 161 . 
substantive economic strategy promoted by the European Council, the rise of this institution to the helm of decision making in economic affairs is a structural institutional development in the architecture of the European Union which must be reckoned with.

\section{Problem and Proposal: Strengthening the Presidency of the EUROPEAN COUNCIL}

As the previous parts have explained, the resilience of austerity in Europe is the result of a growing imbalance between the member states, with Germany playing a dominating role in the EU decision-making process. Yet, this state of affairs is the outcome of a structural institutional development, in which the European Council has risen to the helm in governing economic policy in the European Union. Nevertheless, the role that the European Council has come to play in EU economic governance is a problematic development. As Part II explained, the working methods of the European Council follow an intergovernmental logic. And as Part I indicated, in a framework of intergovernmental governance stronger member states will come to dominate others. The Euro-crisis has epitomized this situation, with Germany acquiring a hegemonic position in the EU decision-making process and promoting austerity as the policy to address the crisis. ${ }^{112}$

This institutional state of affairs, however, is not sustainable in the long run. And it is not unsustainable simply because it is Germany that is currently calling the shots, or because it is austerity that is now being promoted. Rather, this institutional state of affairs is unsustainable because it strikes at the heart of the constitutional balance on which the European Union, as a union of states and citizens, is founded.113 The project of European integration is inherently built on an anti-hegemonic idea, bred in the tragic experiences of two world wars and secular attempts by European states to subjugate each other. ${ }^{114}$ Because of the European history, a shift in the EU institutional framework to a system in which some member states dominate over the others is simply untenable. ${ }^{115}$ As Paul Magnette and Kalypso Nicolaïdis have put it, "[In

112. See Paterson, supra note 28, at 57; see also GLENCROSS, supra note 45, at 305.

113. See Simone Bunse \& Kalypso Nicolaïdis, Large Versus Small States: AntiHegemony and the Politics of Shared Leadership, in THE OXFORD HANDBOOK OF THE EUROPEAN UNION 249, 251-57 (Erik Jones et al. eds., 2012).

114. See Fabbrini, supra note 20 , at 20.

115. The fact that Europe is built on an anti-hegemonic project makes unconvincing the idea that a Franco-German couple must be the engine of European integration. See, e.g., Wolfgang Schäuble, German Minister of Finance, Speech at the European University Institute (Mar. 7, 2012) (defending special role of the entente between Germany and France). While for historical reasons agreement between France and Germany is 
the European Union,] legitimacy largely depends on the trust of all constitutive parts: if some states felt that they are considered as minor elements by the large states, their confidence would be low and the overall level of legitimacy of the EU would be undermined."116

In fact, the events occurring since the eruption of the Euro-crisis have precisely confirmed the risk associated with interstate domination emerging in intergovernmental frameworks. Massive street protests against austerity in national capitals throughout the European Union targeted citizen anger against Germany, which was perceived as illegitimately imposing its policy preferences on the rest of the European Union. ${ }^{117}$ Citizens in a plurality of smaller, economically weaker member states-but now also in larger countries of the Eurozone-have expressed their discontent toward a system that they feel unable to influence by increasingly casting their ballots for extremist, anti-system parties-as evident both in the latest national ${ }^{118}$ and European elections. ${ }^{119}$ In the absence of adequate fora at the European level in which to voice alternative economic blueprints to address the Euro-crisis, the option of exit from the EMU has returned to the table as a least-worse alternative to the current state of affairs, in which foreign countries decide economic governance subject to limited constraints. ${ }^{120}$ The management of the Euro-crisis by the European Council and the domination by some states over others within the functioning of this intergovernmental framework has produced a major problem of legitimacy in the European Union. ${ }^{121}$

important to move the integration process, these are just two members in a complex and pluralist union of states and citizens.

116. Paul Magnette \& Kalypso Nicolaïdis, Large and Small Member States in the European Union: Reinventing the Balance 31 (Notre Europe Research Paper No. 25, 2003).

117. See Sergio Fabbrini, Intergovernmentalism and Its Limits: Assessing the European Union's Answer to the Euro Crisis, 46 CoMP. POL. STUD. 1003, 1022 (2013).

118. See Nicole Scicluna, Politicization Without Democratization: How the Eurozone Crisis Is Transforming EU Law and Politics, 12 INT'L J. CONST. L. 545, 550-53 (2014) (discussing the rise of extreme parties in Greece following the crisis).

119. See Corinne Deloy \& Pascale Joannin, Les forces de droite sortent victorieuses des élections européennes marquées par une poussée populiste dans plusiers États membres, Question d'Europe, FONDATION ROBERT ScHUMAN (May 26, 2014), http:/www.robertschuman.eu/fr/questions-d-europe/0314-les-forces-de-droite-sortent-victorieuses-deselections-europeennes-marquees-par-une-poussee (discussing rise in turnout of Euroskeptic, populist parties in a plurality of EU member states during the May 2014 elections to the European Parliament).

120. See Antonio Estella, Potential Exit from the Eurozone: The Case of Spain, 22 IND. J. GLOBAL LEGAL STUD. 95, 96 (2015).

121. See generally JÜRgEN HABERMAS, THE CRISIS OF THE EUROPEAN UNION (Ciaran Cronin trans., 2012) (emphasizing the problems of legitimacy created by a governance system based on "executive federalism"). 
Because of the importance of non-domination in the European Union, the institutional dynamic triggered by the Euro-crisis calls for an urgent reflection on how to reform the EU constitutional architecture in order to restore a fair balance between the member states in the EU decision-making process, and at the same time to ensure the legitimacy of the EU policies set in the economic domain. I want to emphasize, however, that the need for an institutional change in Europe goes beyond the specific problem of austerity. In other words, while austerity and German domination have unleashed this debate, the need for an institutional reform would be equally important if-say-the European Council was dominated by a French-Italian alliance, promoting Keynesian policies of public spending to foster growth. It is in itself the dynamic of domination, with the resulting illegitimacy of the decisions taken under such allocation of powers, that is ultimately a problem for the sustainability of the European Union. And it is for this reason that, while agreeing on the substance of recent proposals to move the EU economic focus away from austerity toward growth, ${ }^{122}$ I fundamentally disagree that this can be done through a new coalition of anti-austerity member states taking control of the European Council as some have suggested. ${ }^{123}$ Alternative institutional ideas must be advanced to address the status quo.

My core proposal is that the European Union should strengthen the role of the President of the European Council as a viable antidote to the dynamics of interstate domination occurring within an intergovernmental setting and as the way to create a genuine space in which a democratic competition on the policies of the European Union can occur. Whereas, in the current form, the European Council has turned into a forum in which larger states (today notably Germany) can dominate the decision-making process, a stronger presidency of the European Council-that is, a President endowed with autonomous power and selected through a proper pan-European democratic process ${ }^{124}$ _could enjoy the capacity to act free from states' control; in

122. See G20 Leaders' Communiqué, Brisbane Summit, 15-16 November 2014, G20.0RG 1 (Nov. 16, 2014), https://g20.org/wp-content/uploads/2014/12/brisbane_g20_leaders_ summit_communique1.pdf (indicating that the highest priority for wealthy nations should be to raise growth and deliver jobs); see also OECD ECONOMIC OUTLOOK: DATABASE INVENTORY (2014) (calling for growth policies).

123. See, e.g., Marco Damilano, Intervista: "In Europa coalizione contro $i$ populisti". Parla Prodi, L'EsPRESso (May 22, 2014) (It.), available at http://espresso.repubblica.it/ plus/articoli/2014/05/22/news/in-europa-e-inevitabile-una-grande-coalizione-dalla-politicaa-twitter-parla-romano-prodi-1.166422 (former European Commission President Romano Prodi arguing for an alliance between Italy, France, and Spain to overtake German control of the European Council).

124. See infra Parts IV-VI. 
fact, to control states so that none of them can impose its preferences on the others. At the same time, a strengthened presidency of the European Council would increase the effectiveness and legitimacy of the executive power within the European Union, by endowing a monocratic office with the authority to exercise effective leadership, ${ }^{125}$ and by securing that this authority is (perceived as) legitimate because it is directly connected to the people's will. ${ }^{126}$

In proposing to strengthen the President of the European Council, I am aware of the recent efforts that have been made to boost the role of the President of the European Commission. As mentioned in Part II, at the May 2014 European Parliament elections, political parties decided to bring forward lead candidates for the post of Commission President. Jean-Claude Juncker was appointed President of the European Commission through this process. ${ }^{127}$ Many have argued that this process should not be rolled back, as it may develop into something bigger in the future. ${ }^{128}$ In fact, leaving aside the question of whether the Spitzenkandidaten process will be replicated, ${ }^{129}$ it seems that $\mathrm{Mr}$. Juncker has been able to capitalize on the modalities of his appointment as Commission President. ${ }^{130}$ Notwithstanding the explosion of a tax

125. On the problem of leadership in the EU see generally LEADERLESS EUROPE (Jack Hayward ed., 2008). For a criticism of the EU's management of the Euro-crisis-as well as of the ways in which the EU has let the Ukrainian crisis slip out of control-see GEORGE SOROS, THE TRAGEDY OF THE EUROPEAN UNION: DISINTEGRATION OR REVIVAL? (2014).

126. Note that in this article I am using the concept of legitimacy to refer to input legitimacy, or "process legitimacy." See Joseph H.H. Weiler, The Political and Legal Culture of European Integration: An Exploratory Essay, 9 INT'L J. CoNST. L. 678, 682 (2011) (distinguishing between input legitimacy, i.e., electoral legitimacy; output legitimacy, i.e., legitimacy based on the results of EU integration; and Messianic legitimacy, i.e., the legitimacy deriving from the narrative about the good of EU integration).

127. See supra pp. 287-88.

128. See, e.g., Yves Bertoncini, New President, New “Constitution”?, NoTRE EUR. TRIB. VIEWPOINT, July 23, 2014, available at http://www.notre-europe.eu/media/ newpresidentcommission-bertoncini-ne-jdi-july 14.pdf?pdf $=$ ok.

129. European Council Conclusions, supra note 93, at 11 (stating that to address strong concerns by the United Kingdom, "the European Council will consider the process for the appointment of the President of the European Commission for the future, respecting the European Treaties."). But see Daniel Kelemen, Towards a New Constitutional Architecture in the EU?, in WHAT FORM OF GOVERNMENT FOR THE EUROPEAN UNION AND THE EuRozone? 197 (Federico Fabbrini et al. eds., 2015) (suggesting that it will not be feasible to revert to the Spitzenkandidaten process).

130. But see also James Kanter, European Commission Elects a New Leader, N.Y. TIMES, July 15, 2014, http://www.nytimes.com/2014/07/16/world/europe/jean-claudejuncker-elected-head-of-eu-agency.html (emphasizing how Jean-Claude Juncker is a veteran of EU politics and knows well how to play in its intricacies, having been Prime Minister of an EU member state-and thus member of the European Council-for almost twenty years, and having served as President of the Eurogroup from 2005 to 2013). 
scandal concerning Luxembourg (the state where he had been Prime Minister between 1995 and 2001) days after taking office, ${ }^{131} \mathrm{Mr}$. Juncker received from the European Council a mandate to prepare a report on the future of the EMU, coordinating the work of the Presidents of the European Council, the Eurogroup, and the ECB. ${ }^{132} \mathrm{~A}$ preliminary version of this mandate was presented in February 2015.133 This suggests that the prospect of boosting further the executive power of the President of the European Commission remains one of the possible scenarios for the future of EU governance. ${ }^{134}$

Nevertheless, as I have explained elsewhere, the prospect of strengthening the presidency of the European Commission by transforming the European Union into a parliamentary form of government fares badly from the perspective of the balance of power between the member states. ${ }^{135}$ The transition toward a parliamentary regime in which the head of the executive is selected by a parliamentary majority may be suitable to politicize the European Union, but is unable to restore a meaningful balance between the member states and address the problem of domination. Because European Parliament seats are apportioned among member states on the basis of population, albeit subject to a logic of degressive proportionality, ${ }^{136}$ larger states have greater voice in the European Parliament. ${ }^{137}$ However, although the

131. See Matthew Karnitschnig, Luxembourg Tax Leak Puts EU's Juncker Under Further Pressure, WALL ST. J., Nov. 6, 2014, http:/www.wsj.com/articles/luxembourg-taxleak-puts-eus-juncker-under-further-pressure-1415276250 (reporting the disclosure of files indicating that Luxembourg had conceded special tax deals to major multinational corporations during Mr. Juncker's tenure as Prime Minister, and emphasizing political backlash for the new Commission President).

132. See European Council Conclusions EUCO 237/14 of 18 December 2014, 3.

133. Jean-Claude Juncker, President Eur. Com'n, Preparing for Next Steps on Better Economic Governance in the Euro Area: Analytical Note (Feb. 12, 2015), available at http://ec.europa.eu/priorities/docs/economic-governance-note_en.pdf.

134. See Federico Fabbrini, From Executive Federalism to Executive Government: Current Problems and Future Prospects in the Governance of EMU, in WHAT FORM OF GOVERNMENT FOR THE EUROPEAN UNION AND THE EUROZONE? 289, 301(Federico Fabbrini et al. eds., 2015).

135. See Fabbrini, supra note 20, at 27.

136. See TEU, supra note 3, art. 14(2) (stating than no member state can have more than ninety-six seats in the European Parliament and no state shall have less than six).

137. See, e.g., Press Release, European Parliament, Members Elect Chairs and Vicechairs of Parliamentary Committees (July 8, 2014), available at http://www.europarl.europa.eu/ news/en/newsroom/content/20140708IPR51811/html/Members-elect-chairs-and-vice-chairs-ofparliamentary-committees (reporting that of the twenty-two parliamentary committees, five chairs went to MEPs elected in Germany, four to MEPs elected in Poland, three to MEPs elected in Italy, three to MEPs elected in the United Kingdom, two to MEPs elected in France, and two to MEPs elected in Spain, while the three remaining committees will 
European Parliament has endeavored to structure itself along party rather than national lines, ${ }^{138}$ cleavages between the member states are evident within the European Parliament ${ }^{139}$ - in fact, they have been dramatized by the Euro-crisis. ${ }^{140}$ In this context, an institutional solution that entirely shifts to the Parliament the decision on the election of the President of the European Commission is liable to deepen the cleavage between larger and smaller states, entrenching, albeit in a different form, the asymmetry that characterizes the EU member states. ${ }^{141}$

From this point of view, the proposal to strengthen the presidency of the European Council-notably by electing the office through a mechanism that tempers majoritarianism with federal concerns ${ }^{142}$-can prevent the resurgence of dynamics of interstate domination and create a real forum in which EU citizens can voice competing visions of the European Union. The initiative to strengthen the President of the European Commission by connecting his or her appointment to the results of parliamentary elections follows a constitutional logic of fusion of powers in which the government fulcrum rests on the continuum between the parliamentary majority and the cabinet. Conversely, the proposal to strengthen the President of the European Council follows a constitutional logic of separation of powers in which power is divided, and shared, by multiple institutions checking and balancing each other. In a regime of fusion of powers, one institution would be in charge of running the European Union. However, given the profound asymmetries that characterize the EU member states, the European Union cannot afford to be governed by a single institution, be it a congress of heads of state or government, or a parliamentary assembly giving its confidence to the executive.143 As a union of states and citizens, the European Union can only prosper in an institutional regime in which separated institutions, each reflecting different logics of

be chaired by an MEP elected in Bulgaria, an MEP elected in Sweden, and an MEP elected in the Czech Republic).

138. See, e.g., Simon HIX \& BJøRn HøyLand, The Political System OF THE EUROPEAN UNION 130-140 (2011).

139. See Anna Kocharov, In the Image of State: Constitutional Complexities of Engineering a European Democracy, in WHAT FORM OF GOVERNMENT FOR THE EUROPEAN UNION AND THE EUROZONE? 233 (Federico Fabbrini et al. eds., 2015).

140. See Fritz Scharpf, Legitimacy Intermediation in the Multilevel European Polity and Its Collapse in the Eurocrisis, in THE EUROPEAN UNION IN CRISIS OR THE EUROPEAN UNION AS CRISES? 93, 131 (John Erik Fossum \& Augustin José Menéndez eds., 2014).

141. See also Andrea Gratteri, Parlamento e Commissione: Il difficile equilibrio fra rappresentanza e governabilità nell'Unione Europea, 2 COMUNITÀ INTERNAZIONALE 237, 241 (2014).

142. See infra Part V.

143. See Fabbrini, supra note 20 , at 31. 
representation, share the power. ${ }^{144}$ Strengthening the executive power of the President of the European Council would be a step toward embracing separation of powers in the European Union.

At the same time, the idea of strengthening the presidency of the European Council builds on a recent set of EU constitutional reformsas well as on the latest practice of the EU institutions. The position of European Council President was introduced at the time of the European Convention that drafted the EU Constitutional Treaty in 2002-2003.145 Whereas previously the presidency of the European Council tracked the presidency of the Council-rotating every six months between the member states ${ }^{146}$ - the Convention decided to formally recognize the European Council as an EU institution endowed with executive tasks, ${ }^{147}$ and to create the position of European Council President as a way to ensure continuity in the work of the European Council and to steer the direction of the institution. ${ }^{148}$ The proposal to endow the European Council with a semipermanent president was strongly endorsed by the larger member states (who saw in this a way to recognize the reality of states' power) and equally strongly resisted by the smaller member states (who saw in this a fundamental alteration of the principle of states' equality)..$^{149}$ Eventually, under the auspices of Convention President Valéry Giscard d'Estaing, ${ }^{150}$ the presidency of the European Council made its way into the Constitutional Treaty - and then into the Lisbon Treaty. ${ }^{151}$

144. See also Sergio FabBrini, Which EUROPEAN UNION? EUROPE AFTER THE EURO CRISIS (2015) (defending the logic of separation of powers in the EU).

145. See Philippe de Schoutheete, The European Council, in THE Institutions of THE EURoPEAN UNION 43, 48 (John Peterson \& Michael Shackleton eds., 2012).

146. See Treaty Establishing the European Economic Community art. 146, Mar. 25, 1957, 298 U.N.T.S. 11 [hereinafter TEC] (stating that the office of President of the Council shall be held in turn by each member state for a term of six months).

147. Cf. TEU, supra note 3 , art. 15(1).

148. See Ben Crum, Accountability and the Personalisation of the European Council Presidency, 31 J. EUR. INTEGRATION 685, 685 (2009) (arguing that a permanent European Council president would increase democratic representation and accountability throughout the organization).

149. See Magnette \& Nicolaidis, supra note 116, at 15-18 (arguing that the bargaining positions of states at the Convention regarding the European Council President were divided based on the size of the states).

150. See Paul Magnette, Vers un changement de "régime politique"?, in GENESIS AND DESTINY OF THE EUROPEAN CONSTITUTION 1065, 1067 (Giuliano Amato et al. eds., 2007) (discussing the influence of the French constitutional mindset over the institutionalization of the presidency of the European Council. Institutionalization was strongly favored by European Convention President Valéry Giscard D'Estaing, a former President of the French Fifth Republic).

151. Paul Craig, The Lisbon Treaty: Law, Politics and Treaty Reform 78 (2010). 
However, whereas in the Giscardian vision the President of the European Council ought to have been a strong figure, the text of the Constitutional Treaty, and then the Lisbon Treaty, constrained its status and functions to address the concerns of the smaller member states. ${ }^{152}$ First, the President is entitled to head the European Councilnot the European Union as such. ${ }^{153}$ Second, the President is elected by a qualified majority of the heads of state and government congressed in the European Council and can be removed by them according to the same procedure in the event of an impediment or a serious misconduct. ${ }^{154}$ Third, contrary to institutions such as the Parliament, ${ }^{155}$ or (generally) the Commission, ${ }^{156}$ whose members are elected for a fiveyear term, the President of the European Council remains in office for a term of two and a half years, renewable only once. ${ }^{157}$ And fourth, the President is empowered to act more as a chairperson of that institution than as an executive leader. ${ }^{158}$ Each of these solutions restricted the role of the President, closely tying him to his peers within the European Council, ${ }^{159}$ and deprived him of a substantial capacity to shape the agenda, on the assumption that this would better maintain the influence of smaller member states on the working of the institution. Yet, each of these solutions ultimately worked against the interest of the smaller member states. ${ }^{160}$ Ironically, in a context in which the President of the European Council enjoyed limited power and legitimacy, it was easier for the biggest member states to impose their preferences.

This is not to deny that the first President of the European Council-Mr. Herman Van Rompuy, a former Prime Minister of

152. See Paolo Ponzano, Les institutions de l'Union, in Genesis AND DesTINY OF THE EUROPEAN CONSTITUTION 439, 467 (Giuliano Amato et al. eds., 2007) (explaining that the Treaty sought to limit the powers of the President).

153. See TEU, supra note 3, art. 15(6)(a) (indicating that the President is to chair the European Council and "drive forward its work").

154. Id. art 15(5).

155. See id. art. 14(3) (stating that "members of the European Parliament shall be elected for a term of five years").

156. See id. art. 17(3) (stating that "[t]he Commission's term of office shall be five years"). But see id. art. 17(8) (stating that "the European Parliament may vote on a motion of censure of the Commission.").

157. Id. art. 15(5).

158. Id. art. 15(6).

159. See CRAIG, supra note 151, at 117 (stating that the current "appointment procedure for the Presidency of the European Council places the power firmly in the hands of that body").

160. See generally Fabbrini, supra note 20 (describing the shift of power in the EU from smaller member states to larger ones). 
Belgium, appointed for two and a half years in November 2009161 and renewed for a second mandate in March 2012162 -made inroads into consolidating the position of the presidency and its function in brokering compromises between the member states. ${ }^{163}$ As it has been pointed out, President Van Rompuy has "succeeded in becoming an influential actor in his own right, through a dutiful exercise of his official powers, clever exploitation of some legal 'grey zones', and tactful dealing with the Union's other institutional players."164 In particular, President Van Rompuy skillfully invested himself with important responsibilities in the governance of the EMU, leading the work of two task forces that prepared the roadmap of the legal and policy responses to the Eurocrisis by the EU institutions and the member states. ${ }^{165}$ In fact, at the official handover ceremony with his successor-Donald Tusk, the former Prime Minister of Poland, who was elected in August 2014 as the second President of the European Council ${ }^{166}-\mathrm{Mr}$. Van Rompuy affirmed that the "President of the European Council represents the Union as a whole." 167 Although technically this is incorrect, since as just mentioned Article 15 of the TEU only vests in the President the role of representing the European Council, the statement signals a push toward a kind of presidentialization of EU governance. ${ }^{168}$

Nevertheless, the prospects for such a development remain limited under the current constitutional arrangement. Under the existing treaties, the President of the European Council acts mainly as a deal broker facilitating compromises between member states, and is almost exclusively endowed with internal procedural powers. ${ }^{169}$ As President Van Rompuy himself put it, his main task is to listen to the heads of states and government and to build trust between them. ${ }^{170}$ In fact, there

161. Press Release, European Council (Nov. 19, 2009).

162. Press Release, European Council (Mar. 1, 2012), EUCO 37/12.

163. See Henri De Waele \& Hansko Broeksteeg, The Semi-Permanent European Council Presidency: Some Reflections on the Law and Early Practice, 49 COMMON MKT. L. REv. 1039 (2012) (studying the changing role and power of the European Council President over time).

164. Id. at 1070 .

165. See generally Report of the Task Force to the European Council, supra note 86. See also President of the European Council, Towards a Genuine Economic and Monetary Union, 4-5 (Dec. 5, 2012), available at http://www.consilium.europa.eu/uedocs/cms_Data/ docs/pressdata/en/ec/134069.pdf.

166. See European Council Conclusions, EUCO 163/14 of 30 August 2014, 2.

167. President Herman Van Rompuy, Remarks at the Handover Ceremony with President of the European Council Donald Tusk (Dec. 1, 2014), in EUCO 257/14, at 1.

168. See De Waele \& Broeksteeg, supra note 163, at 1074.

169. PUETTER, supra note 71, at 114.

170. Herman Van Rompuy, Pres. Eur. Coun., Speech on "Looking Back, Looking Forward", at The State of the Union Conference, Accademia dei Lincei Rome (Nov. 7, 
is evidence that Germany, the biggest EU member state, has played a privileged role in influencing the European Council and its President.171 The risks that a weaker presidency would pose to the balance of power between the member states had not gone unnoticed during the debates of the Constitutional Convention.172 Then Greek Foreign Minister Georgios Papandreou, for instance, had tabled an amendment to introduce the direct election of the President of the European Council and justified the proposal stating that "a directly elected President would strengthen the role of the European citizen, contribute to the substantial equality of the member states and facilitate a new, stable balance between the institutions." 173

This article argues that the recent trend toward the consolidation of the presidency of the European Council should be supported by adequate institutional reforms that strengthen the office so as to make it truly the President of the Union as a whole. In constitutional terms, this implies both new powers and new legitimacy for the institution. On the one hand, the presidency should be vested with the legal capacity to make authoritative decisions. ${ }^{174}$ The new presidency should have the power "to take executive economic policy decisions for the EMU."175 The President should have the authority to set the agenda he or she believes to be in the best interest of the Union-resisting pressure from the heads of state and governments (and especially the more powerful among them), rather than reflecting their preferences. On the other hand, this extended authority should be connected to, and supported by, a process of legitimation-that is, a selection mechanism that is

2014), in EUCO 264/14, at 4 (stating that on the basis of the Treaty "the job description and formal competencies of [the] President are rather vague, even meagre" and claiming that in his experience "[b]uilding trust is . . perhaps the most important task of a European Council President.").

171. See Herman Van Rompuy, Pres. Eur. Coun., Farewell Speech to the Members of the European Council (Oct. 24, 2014), in EUCO 232/14, at 1 (thanking explicitly only German Chancellor Angela Merkel).

172. See Magnette \& Nicolaïdis, supra note 116, at 15 (noting the rationales for the larger states' plan to strengthen the office of the President of the European Council).

173. Secretariat, Summary Sheet of Proposals for Amendments, CONV 709/03 (May 9, 2003).

174. See Miguel Poiares Maduro, Foreword: Fiscal Capacity and Constitutional Reform in the EMU, in THE CONSTITUTIONALIZATION OF EUROPEAN BUDGETARY CONSTRAINTS v, vii (Federico Fabbrini et al. eds., 2014) (making the case for a new political authority in the EU).

175. See President of the European Council, supra note 165, at 17 (Dec. 5, 2012) (stating that the crisis has "shown the need to strengthen ... the EMU's . . . ability to take rapid executive decisions to improve crisis management in bad times and economic policymaking in good times. ... Reinforcing the capacity of the European level to take executive economic policy decisions for the EMU is essential."). 
perceived as legitimate by the people throughout the European Union. ${ }^{176}$ In a democratic system, such a mechanism can only be the electoral process. ${ }^{177}$

The proposal to strengthen the role of the President of the European Council has so far not received much scholarly or political attention. ${ }^{178}$ Although proposals for institutional reform have abounded during the last few years, ${ }^{179}$ the initiatives to strengthen the executive power of the European Union focused mainly on the role of the President of the European Commission. A proposal articulated by individual policy makers ${ }^{180}$-and also considered by some within the so-called Berlin Group (the Foreign Affairs Ministers of Austria, Belgium, Denmark, France, Italy, Germany, Luxembourg, the Netherlands, Poland, Portugal, and Spain) in its September 2012 report on "The Future of Europe"181_would introduce the direct election of the President of the European Commission. ${ }^{182}$ Nevertheless, this proposal is very different from the one advanced here, since it would essentially introduce a "neoparliamentary" form of government in the European Union ${ }^{183}$ _i.e., a system in which citizens directly elect a chamber of the legislature as well as the head of the cabinet, who should then obtain the confidence of

176. See Wojcech Sadurski, Democratic Legitimacy of the European Union: A Diagnosis and Some Modest Proposals, 32 POL. Y.B. INT'L L. 9, 13 (2013) (arguing that the EU suffers from a crisis of legitimacy and that "for the Union to maintain (or acquire, depending on one's perspectives) a modicum of legitimacy, it must be democratic.").

177. See generally Yves Mény, De la démocratie en Europe: Old Concepts, New Challenges, 41 J. COMMON MKT. STUD. 1 (2002) (emphasizing the importance of popular input while underlying the need for a fresh approach to the problem of democracy).

178. But see DAVID MARQUAND, THE END OF THE WEST: THE ONCE AND FUTURE EURoPE 137 (2011); Sergio Fabbrini, After the Euro-Crisis: The President of Europe, EuRopEos COMMENTARY No. 12, June 2012, at 5, 6.

179. See, e.g., INGOLF PERNICE ET AL., A DEMOCRATIC SOLUTION TO THE CRISIS: REFORM STEPS TOWARDS A DEMOCRATICALLY BASED ECONOMIC AND FINANCIAL CONSTITUTION FOR EUROPE 83 (2012); Deirdre Curtin, Challenging Executive Dominance in European Democracy, 77 MOD. L. REV. 1, 18 (2014).

180. See Wolfgang Schäuble, Ger. Minister of Fin., Speech on "The State of Europe: What Governance is Needed in the European Union?" at the Hertie School of Governance, (May 27, 2014).

181. See Berlin Group, Final Report of the Future of Europe Group of the Foreign Ministers of Austria, Belgium, Denmark, France, Italy, Germany, Luxembourg, the Netherlands, Poland, Portugal and Spain, 9 (Sept. 17, 2012) (stating that "For some members of the Group, this could include . . . a directly elected Commission President who appoints the members of his 'European Government' himself .").

182. See also Frank Decker \& Jared Sonnicksen, The Direct Election of the Commission President: A Presidential Approach to Democratizing the European Union, ZEI DISCUSSION PAPER No. C192, 2009, at 24-30.

183. See Francesco Clementi, L'elezione diretta del Primo ministro: l'origine francese, il caso israeliano, il dibattito in Italia, 20 QUADERNI COSTITUZIONALI 579 (2000) (explaining the functioning of a "neo-parliamentary" form of government). 
the legislature. ${ }^{184}$ Yet, comparative analysis makes clear that this form of government has proved to be largely dysfunctional. Between 1996 and 2001 , Israel briefly experimented with this system of government, ${ }^{185}$ but quickly abandoned it in light of the tensions emerging between the majority-based election of the Prime Minister and the proportionalitybased election of the Knesset, as well as the incapacity to master conflicts between the executive and the legislature. ${ }^{186}$

The proposal to strengthen the presidency of the European Council follows a different logic. While the idea may be reminiscent of a semipresidential regime akin to the French model, in which a directly elected head of state coexists with a cabinet and parliament linked by a relationship of confidence, ${ }^{187}$ the proposal to strengthen the President of the European Council essentially follows the logic of separation of powers. ${ }^{188}$ The French constitutional system is characterized-save in times of cohabitation ${ }^{189}$-by a marked hierarchical relationship between the directly elected President, the Prime Minister, and Parliament, 190 and by the remarkable absence of checks and balances on the presidency. ${ }^{191}$ In the European Union, instead, there is a clear separation of powers between the European Council and the European

184. Proposals in favor of the direct election of the President of the European Commission do not consider this point. However, by not setting aside the power of the European Parliament to give a vote of approval for the President of the Commission, they de facto endorse the creation of a "neo-parliamentary" regime.

185. See Basic Law: The Government, 5752-1992, SH No. 1396 p. 214 (Isr.) (introducing direct election of Prime Minister) and Basic Law: The Government, 5761-2001, SH No. 1780 p. 158 (Isr.) (abolishing previous reform).

186. See Emanuele Ottolenghi, Choosing a Prime Minister: Executive-Legislative Relations in Israel in the 1990s, 10 J. LEGIS. STUD. 263, 263 (2004).

187. See Maurice Duverger, A New Political System Model: Semi-Presidential Government, 8 EUR. J. POL. RES. 165, 165 (1980).

188. See supra text accompanying note 144 .

189. See generally Jean Gicquel, De la cohabitation, 49 Pouvorns 69 (1989) (explaining that a cohabitation arises whenever the President and the parliamentary majority, and thus the Prime Minister, belong to different political parties). But see Loi constitutionnelle 2000-964 du 2 octobre 2000 relative à la durée du mandat du Président de la République [Constitutional Law 2000-964 of October 2, 2000 on the Term of Office of the President of the Republic], JOURNAL OFFICIEL DE LA REPUBLIQUE FRANÇAIS [J.O.] [OFFICIAL GAZETTE OF FRANCE], Oct. 3, 2000, p. 15582 (modifying Art. 61958 CoNST. Fr. to reduce the length of the presidential mandate to five years). The effect of this reform has been to bring close to nil the probability of a cohabitation. See Stefano Ceccanti, Le istituzioni e il sistema politico dopo il primo "quinquennato", in LA FRANCIA DI SARKOZY 27 (Gianfranco Baldini \& Marc Lazar eds., 2007).

190. See Olivier Duhamel, Remarques sur la notion de régime semi-présidentiel, in DROIT, INSTITUTIONS ET SYSTEMES POLITIQUES 581, 581 (1987).

191. See MAURO VOLPI, LIBERTÀ E AUTORITÀ: LA CLASSIFICAZIONE DELLE FORME DI STATO E DI GOVERNo 146 (2007) (defining the French form of government as "hyperpresidentialist"). 
Parliament, since the former cannot dissolve the latter and the latter cannot vote out the former. ${ }^{192}$ The proposal to strengthen the presidency of the European Council advanced here builds on and develops this logic of separation of powers, and is therefore reminiscent of constitutional systems, such as in the United States where the executive and the legislature check and balance each other. ${ }^{193}$ Even so, contrary to the U.S. system, which is characterized by a unitary executive, ${ }^{194}$ in the European Union the executive power remains fragmented. 195 This feature makes the EU form of government peculiar-and, thus, the proposal to strengthen the presidency of the European Council in need of further analysis.

Because the proposal to strengthen the President of the European Council has not received much attention in the European constitutional law literature, it is necessary to more fully articulate what such a change would entail. I will attempt this in the remainder of this article. This requires asking three questions. First, what are the advantages associated with the establishment of a more solid presidency, and how should these be reflected in the new powers that would be attributed to the institution? Second, what should be the mechanism to elect the President of the European Council, and how can the asymmetry in population between the EU member states be reconciled with the choice of the holder of a monocratic office? Third, what are the challenges facing the road toward changing the EU treaties to strengthen the presidency, and how could these practical difficulties be addressed in the framework of the ongoing debate about the future of the EMU? In considering each of those questions, I will try to use as a compass the lessons provided by the comparative constitutional law literature on forms of government. ${ }^{196}$ However, I am aware that I am entering unchartered territory, and I do not doubt that many of my arguments will be subject to criticism and require further refinement. I hope, however, that by starting this debate I will draw scholarly attention to

192. See also SERGIO FABBRINI, COMPOUND DEMOCRACIES 186-87 (2007).

193. See Amie Kreppel, Understanding the European Parliament from a Federalist Perspective, in CoMParative Federalism: THE EuROPEAN UNION AND THE UNITEd STATES IN COMPARATIVE PERSPECTIVE 245 (Anand Menon \& Martin Schain eds., 2006).

194. See U.S. CONST. art II, $\S 1$ (stating that "The executive Power shall be vested in a President of the United States."). See generally Mark Tushnet, A Political Perspective on the Theory of the Unitary Executive, 12 U. PA. J. ConsT. L. 313 (2010) (discussing the theory of the unitary executive in the United States, with its variants of intensity).

195. Deirdre Curtin, ExecUtive Power of the European UnION: LAW, PRACTiCeS, AND THE LIVING CONSTITUTION 69 (2009).

196. See generally THE EXeCUTtVe AND PUBLIC LAW: PowER AND ACCOUNTABILITY IN Comparative PERSPECTIVe (Paul Craig \& Adam Tomkins eds., 2006) (discussing role of executive branches in Europe and other countries). 
the merits of this option of institutional reform to improve the governance of the European Union through reflection and choice, rather than through accident and force. ${ }^{197}$

\section{POWER AND REPRESENTATION}

The proposal to strengthen the role of the President of the European Council moves the European Union toward the advantages of a presidential form of government.198 Scholars comparing parliamentarianism and presidentialism have underlined how each of these forms of government or their hybrids, semi-presidentialism or neoparliamentarianism, has both pros and cons. ${ }^{199}$ However, among the virtues of presidential systems, a political regime in which the people select the President separately and independently from the legislature, scholars usually identify several recurring general benefits. ${ }^{200}$ Presidential systems favor governmental stability because they ensure the continuity in office of the President for the entire length of the elected term, regardless of the ongoing confidence of the legislature, as is the case in parliamentary and neoparliamentary regimes. Presidential systems provide greater governmental vigor and leadership because they vest the executive power (or part thereof) into a monocratic office. Moreover, presidential systems endow the citizens with the capacity to directly select the president, removing this power from the legislature and ensuring a direct, rather than mediated, legitimacy to the chief executive. Presidential systems also inject a majoritarian logic into the political system, forcing relevant societal actors to polarize along key political cleavages and counterbalancing the fragmentation that is inherent whenever the electoral system is based on proportional representation.

197. See THE FEDERAlist No. 1, at 6 (Alexander Hamilton) (Jim Manis, ed., 2001) (asking "whether societies of men are really capable or not of establishing good government from reflection and choice, or whether they are forever destined to depend for their political constitutions on accident and force.").

198. See also Hodson \& Puetter, supra note 84, at 373 (emphasizing "presidentialization of euro area governance"); De Waele \& Broeksteeg, supra note 168 (stating that in due time "the EU's system of government might well be ascribed a genuine presidential epithet.").

199. See Giovanni Sartori, Comparative Constitutional Engineering 126-31 (1994); AUgusto Barbera \& CaRlo FUSARO, IL gOVERNo DELle DEMOCRAZIE 79 (2001); MAURICE DUVERGER, INSTITUTIONS POLITIQUES ET DROIT CONSTITUTIONNEL (1978) (comparing forms of government).

200. See Steven G. Calabresi, The Virtues of Presidential Government, 18 ConsT. Comment. 51, 54 (2001). But see Richard Albert, Presidential Values in Parliamentary Democracies, 8 INT'L J. CoNST. L. 207, 208 (2010) (emphasizing how parliamentary regimes may be able to embody the virtues of presidential government). 
The virtues of a vigorous, directly legitimated and majoritarian presidency may be particularly valuable in the European Union today. ${ }^{201}$ Although the European Union does not suffer from the institutional instability characteristic of a parliamentary regimebecause the Commission is voted in office by Parliament for a term of five years and can only be removed by it $^{202}$ on the basis of a procedure which is more reminiscent of the impeachment process in presidential systems, than of the vote of no-confidence in parliamentary regimes ${ }^{203}$ there is growing awareness that the European Union currently lacks an effective and legitimate executive branch. ${ }^{204}$ Whereas the European Union's responses to the Euro-crisis have been described as slow and weak, the existence of a stronger presidency would increase the capacity to act swiftly and with leadership in front of new challenges.205 Moreover, whereas the EU institutions currently appear very much remote from the EU citizens-since the mechanisms of electoral accountability at the EU level are only indirect206_the existence of a stronger presidency, directly legitimated by the citizens, would raise its capacity to be responsive to popular concerns. ${ }^{207}$ At the same time, while the current proportionality-based electoral regime for the European Parliament ${ }^{208}$ favors party fragmentation and fosters the lack of unifying themes in the European political debate, ${ }^{209}$ the existence of a monocratic office would inevitably force the emergence of a public

201. But see AREND LIJPHART, PATTERNS OF DEMOCRACY 42 (1999) (describing the EU as the example of a consociational system, following non-majoritarian logics).

202. See TEU supra note 3, art. 17(3).

203. See Paul Magnette, Appointing and Censuring the European Commission: The Adaptation of Parliamentary Institutions to the Community Context, 7 EUR. L.J. 292, 305 (2001) (emphasizing technocratic rather than the political nature of the motion of censure by the European Parliament).

204. See supra p. 294.

205. See Sylvie Goulard, Foreword: De la démocratie en Europe, in WHAT FORM OF GOVERNMENT FOR THE EUROPEAN UNION AND THE EUROzONE? v (Federico Fabbrini et al eds., 2015).

206. But see Peter L. LindSeth, Power AND Legitimacy 22-23 (2010) (arguing that the $\mathrm{EU}$ is based on a delegation of powers by the member states with the legitimacy solidly residing in them).

207. See Laeken Declaration, SN 273/01 (Dec. 15, 2001) (stating that "the European institutions must be brought closer to its citizens" so as to address the democratic challenge facing the $\mathrm{EU}$ ).

208. See Council Decision 2002/772/EC, art.1, 2002 O.J. (L 283) 1, (Euratom) (amending the Act concerning the election of the representatives of the European Parliament by direct universal suffrage and requiring member states to adopt proportional representation for the elections of the European Parliament).

209. See Michel Theys, Vingt-huit scrutins nationaux pour un Parlement en constante évolution, EGMONT ROYAl INST. FOR INT'L REL. EUR. POL'Y BRIEF No. 26 (2014) (emphasizing fragmentation of European Parliament elections along national lines). 
sphere, where competition occurs around key lines of political conflict, and would thus likely contribute to the rise of European political parties. $^{210}$

In the institutional system of the European Union, however, the proposal to strengthen the role of the President of the European Council would carry additional benefits that are specific to the present situation of the European Union. First, a reformed presidency of the European Council, selected through an open and transparent electoral process and accountable to EU citizens at large, would restore a healthy equality between the EU member states. A fair balance between the member states is crucial to a well-functioning European Union. ${ }^{211}$ At the moment, however, the President of the European Council is chosen by the heads of states and government congressed in the European Council, and is accountable exclusively to them. ${ }^{212}$ This means that, currently, the President is entirely dependent on the heads of states and governments and enjoys limited capacity to keep them under check. ${ }^{213}$ As the previous analysis underlined, Germany has acquired a dominating influence in the working of the European Council, largely upsetting the balance between the member states. ${ }^{214}$ Were the President of the European Council to be chosen through a popular election instead, he could have the institutional independence to keep the member states in check and protect the interests of the Union as a whole.

Strictly linked to this is a second advantage of the presidentialization of the European Council, which carries particular value in the current state of the $\mathrm{EU}$ integration project: the capacity to provide a sense of unity. It has been too often noticed how growing fragmentation within the European Union-with the partition between the Eurozone and the non-Eurozone member states, ${ }^{215}$ increasing resort

210. See generally Ingolf Pernice, Domestic Courts, Constitutional Constraints and European Democracy: What Solution for the Crisis?, in THE CONSTITUTIONALIZATION OF EUROPEAN BUDGETARY CONSTRAINTS 297, 316 (Federico Fabbrini et al. eds., 2014) (discussing the importance of a European public sphere).

211. See generally Magnette \& Nicolaïdis, supra note 116 (discussing why a fair balance is required by small and large states in the EU for it function effectively).

212. See TEU, supra note 3, art. 15(5).

213. See generally D. Nederlof et al., Editorial, The European Council and National Executives: Segmentation, Consolidation and Legitimation, 8 EUR. CONST. L. REV. 165, 165-71 (2012).

214. See supra pp. 278-284.

215. See generally JEAN-ClaUde PIRIS, THE FUTURE OF EUROPE: TOWARDS A TwO-SPEED EU? (2011) (noting the fragmentation caused by the division between Eurozone and nonEurozone members, and proposing the solution of permitting two-speed development, allowing a move toward closer economic and political union). 
to enhanced cooperation, ${ }^{216}$ and the complex patterns of intergovernmental agreements concluded by member states with variable geometry outside the legal order of the European Union, 217 has weakened the idea of unity of the Union. ${ }^{218}$ Needless to say, a complex polity like the European Union shall be pluralistic and provide for multiple fora for representation, 219 and the right to withdrawal from the European Union, which is currently enshrined in the EU treaties, makes sure that no member state can be compelled to remain part of the European Union against its will. ${ }^{220}$ Nevertheless, there is a case to be made for the European Union to be able to increasingly speak with one voice, both to face security challenges abroad, and to define the interests of the European Union at home.221 From this point of view, strengthening the role of the President of the European Council would offer the institutional forum through which the multiple interests at play in the European Union could be integrated into a unitary vision.

Further, a third advantage connected with a reformed post of the European Council President is its suitability to protect the values of federalism (or decentralization) on which the European Union is founded. Scholars of federalism have emphasized this point, 222 but it is worth restating here to allay the fears of those who worry that a strong President of the European Council, representing the unity of the Union, would make the European Union slide into the direction of a super-

216. See Federico Fabbrini, Enhanced Cooperation Under Scrutiny: Revisiting the Law and Practice of Multi-Speed Integration in Light of the First Involvement of the EU Judiciary, 40 LEGAL IsSUES ECON. INTEGRATION 197, 199 (2013).

217. European Parliament Resolution of 12 December 2013 on Constitutional Problems of a Multitier Governance in the European Union, EUR. PARL. DOC. P7_TA(2013)0598.

218. See W. Tom Eijsbouts \& Monica Claes, Editorial, From Confederacy to Convoy: Thoughts About the Finality of the Union and its Member States, 6 EUR. CONST. L. REV. 1, $1-5$ (2010).

219. See generally Walter van Gerven, The European Union: A Polity of States AND PEOPLE (2005) (highlighting that the complex polity of EU requires it to be pluralistic).

220. See TEU, supra note 3, art. 50.

221. See Glienicker Group, Towards a Euro Union, (Oct. 18, 2013), http://www.bruegel.org/nc/blog/detail/article/1173-towards-a-euro-union/ (stating that "[i]n a multipolar world in which China, Russia and others expand their spheres of influence and the global supremacy of the USA decreases, Europe ought to be able to defend her common interests effectively"); Eiffel Group, For a Euro Community, (Feb. 14, 2014), http://www.bruegel.org/nc/blog/detail/article/1250-for-a-euro-community/ (stating that "[e]nsuring that Europe's voice is heard is not a question of prestige, nor an idealist whim. It is how to ensure that in the future the priorities which are important to Europe's citizens ... are protected.").

222. See generally Bradford Clark, Separation of Powers as a Safeguard of Federalism, 79 TEX. L. REv. 1321, 1321-29 (2001) (discussing separation of powers as a protection of federalism in the U.S.). 
state. ${ }^{223}$ In fact, an autonomously legitimated President of the European Council can actually provide a more receptive forum to those EU citizens who would like to scale back the degree, or speed, of EU integration. At the moment, the $\mathrm{EU}$ institutional system does not provide any supranational forum in which disgruntled EU citizens can voice their concern against overcentralization. ${ }^{224}$ The process of EU integration has been characterized by a continuous trend in the centralization of powers, ${ }^{225}$ with the functioning of the EU bureaucracy continuing on autopilot despite the growing disenchantment of EU citizens. ${ }^{226}$ An elected and accountable President of the European Council could provide exactly such a forum and should be endowed with the power to safeguard the federal division of competence between the European Union and its member states. ${ }^{227}$

Ultimately, the three advantages discussed above can be related through the concept of representation. As the Euro-crisis has demonstrated, the European Union lacks an executive body that can simultaneously represent the EU member states and the EU citizens (i.e., a union of states and citizens). ${ }^{228}$ Each of the heads of states and government that sits in the European Council certainly represents its member state and the national constituency that elected him or her;229 but he or she cannot speak for other states or citizens since these have not elected him or her. At the same time, the current President of the

223. See generally GLYN MORGAN, THE IdEA OF A EUROPEAN SUPERSTATE: PUBLIC JUSTIFICATION AND EUROPEAN INTEGRATION (2005) (making the case in favor of a superstate).

224. Compare Damian Chalmers, Democratic Self-Government in Europe: Domestic Solutions to the EU Legitimacy Crisis, POL'Y NETWORK (May 15, 2013), www.policynetwork.net/publications_download.aspx?ID=8362 (advancing a proposal to empower national parliaments to veto and nullify EU legislation), with infra note 249 and accompanying text (explaining that vesting veto power in national parliaments is not the solution to police subsidiarity as national legislatures use their power for domestic political reasons).

225. See generally Ken Kollman, PERILs of CENTRALIZATION: Lessons From CHuRCH, STATE AND CORPORATION (2013) (discussing the trend of centralization in the EU).

226. See Tony Barber, Elections Results Show a Europe Short of Confidence in Its Future, THE FIN. TIMES (London) (May, 26 2014), http://www.ft.com/cms/s/0/49fleab4e4d8-11e3-9b2b-00144feabdc0.html\#slide0.

227. See infra pp. 311-312.

228. See TEU, supra note 3 , art. 10(1) (stating that "[t]he functioning founded on representative democracy."); see also Armin von Bogdandy, The European Lesson for International Democracy: The Significance of Article 9-12 EU Treaty for International Organizations, 23 EUR. J. INT'L L. 315, 315 (2012) (explaining the significance of TEU article $10(1)$ in regards to representative democracy).

229. See Wolfgang Wessels et al., Democratic Control in the Member States of the European Council and the Euro zone Summits, report commissioned by the Constitutional Affairs Committee of the European Parliament, PE 474.392 (Jan. 2013). 
European Council only represents the heads of state and government who elected him, ${ }^{230}$ but he cannot really speak for the Union as a whole, since the EU people never voted him into office. As it is, also the President of the European Commission suffers from an analogous representative deficit, even after the "new process" put in place for the May 2014 election of the European Parliament, in which each political party tied its electoral success with the appointment of a Spitzenkandidat for the post of Commission President. ${ }^{231}$ Because the European Parliament is elected through a system of proportional representation, the composition of the legislature reflects a high degree of fragmentation, and no political party won a majority. ${ }^{232}$ As a result, the President of the European Commission was drawn from the largest party in the European Parliament, the EPP, which only won 29 percent of the EU-wide popular vote. In this situation, it is difficult for the President of the European Commission to claim that he received a popular mandate to represent the Union. ${ }^{233}$

The disconnect between the power that the European Union has acquired since the beginning of the Euro-crisis and the lack of adequate mechanisms of representation is a key challenge for the Union. ${ }^{234}$ No democratic polity can accept the exercise of power in the absence of adequate institutional channels of representation, through which the people can express its voice. ${ }^{235}$ Yet, as it was pointed out in the previous part, the management of the Euro-crisis has deprived an increasing number of EU states and citizens of the capacity to effectively influence the decisions affecting them; this lack of voice has fueled an increasingly popular discontent vis-à-vis measures, which were perceived as illegitimate-as revealed by the electoral surge of extreme, antisystem parties. ${ }^{236}$ It is here that the proposal to strengthen the presidency of the European Council, and make it directly accountable to EU citizens at large, becomes crucial to cure the representation deficit in the $\mathrm{EU}$

230. See CRAIG, supra note 151; HABERMAS, supra note 121.

231. See supra pp. 287-288.

232. See Result of the 2014 European Elections, supra note 92.

233. See Joseph H.H. Weiler, Editorial, Fateful Elections? Investing in the Future of Europe, 25 EUR. J. INT'L L. 361, 365 (2014) (stating that the selection of the Commission President in light of the result of the election of the European Parliament "compromises the ability in a political sense for this or that candidate to say with authority 'I was elected by the peoples of Europe.").

234. See Simona Piattoni, Is the EU a Representative Democracy? The Normative Debate and the Impact of the Euro-Crisis, in WHAT FORM OF GOVERNMEN'T FOR THE EUROPEAN UNION AND THE EUROZONE? 133 (Federico Fabbrini et al. eds., 2015).

235. See generally Ben Crum, Saving the Euro at the Cost of Democracy?, $51 \mathrm{~J}$. Common MKT. STUD. 614, 614 (2013) (discussing the need for adequate institutional channels of representation in relation to the Euro-crisis).

236. See supra notes 118-19. 
executive branch. ${ }^{237}$ If the President of the European Council were elected by the EU citizens, through a mechanism which (as I shall explain below) ${ }^{238}$ accounts for the asymmetries between the EU member states, it could plausibly claim to represent the interest of the Union as a whole and, therefore, be able to act in the name of Europe. This is crucial not only because the President would eventually be able to exercise leadership, but also because it could legitimately speak for the EU citizens and member states, rather than for just a sub-group thereof. 239

In light of the above, it is time to consider how the new powers of the presidency should be defined. From a comparative perspective, the diversity of constitutional regulation of the power of the executive branch in presidential systems is remarkable. For example, the U.S. Constitution barely defines the function of the President, ${ }^{240}$ whereas the French and Brazilian Constitutions provide a broad empowerment of authority to the Head of State. ${ }^{241}$ Most constitutions entrust the

237. See Deirdre Curtin, Democratic Accountability of EU Executive Power, in What FORM OF GOVERNMENT FOR THE EUROPEAN UNION AND THE EUROZONE? 171 (Federico Fabbrini et al. eds., 2015) (discussing the need for institutional reforms that increase accountability of the EU executive).

238. See infra Section V.

239. See ceteris paribus Steven G. Calabresi, Some Normative Arguments for the Unitary Executive, 48 ARK. L. REV. 23, 23-38 (1995) (emphasizing that the presidency in the U.S. constitutional system is the only purely national office, as opposed to the legislature, whose members are representatives of regional, or state, constituencies).

240. See U.S. ConsT. art. II, $\S 2$ (effectively granting to the President alone only the power to command the military, "require the Opinion, in writing, of the principal Officer in each of the executive Departments," grant pardons, and make recess appointmentswith all other powers being subject to Congressional approval). Of course, over the time the effective powers of the presidency have aggrandized, especially in the field of national security and foreign affairs. See also Ernest A. Young, Taming the Most Dangerous Branch: The Scope and Accountability of Executive Power in the United States, in THE EXECUTIVE AND PUBLIC LAW 161 (Paul Craig \& Adam Tomkins eds., 2006). But see NLRB v. Canning, 134 S. Ct. 2550 (2014) (restricting the power of the President to make recess appointments even when the Senate is convened only in pro-forma sessions).

241. Constituição Federal [C.F.] [Constitution] art. 84 (Braz.) (empowering the President, inter alia, to appoint and dismiss ministers of state, run the administration, initiate legislation, veto bills, conclude national treaties, declare a state of siege and emergency, command the military, grant pardons, submit to Congress the pluriannual plan and the budget, and issue provisional measures with the force of law); 1958 CoNST. arts. 5-19 (Fr.) (charging the President of the Republic with guaranteeing the functioning of the public power, the continuity of the state, and national independence; and empowering him to appoint the Prime Minister, preside over the Council of Ministers, veto bills, call for a national referendum, dissolve the assembly, command the military, grant pardons, and exercise emergency powers when the independence of the nation is threatened). 
command of the military to the presidency, ${ }^{242}$ but this is not something that concerns the European Union ${ }^{243}$ (although one may be left wondering how long the Union can expect to go forward without an adequate security and defense policy, in light of rising threats, not only globally, but also regionally). ${ }^{244}$ In the framework of the European Union, it seems that a treaty reform strengthening the power of the President of the European Council should at least award to the presidency the following new powers. First, the President of the European Council should appoint the members of the Commission, which would be subject to the vote of consent of the European Parliament. The Commission is an institution with very professional and qualified technical know.how to administer policy decisions. Therefore, it would be unreasonable to duplicate the task of the Commission by establishing a new administration within the presidency of the European Council. Nevertheless, action by the Commission is increasingly in need of democratic legitimation. ${ }^{245} \mathrm{By}$ virtue of its popular, EU-wide election, the President of the European Council would be able to secure such a legitimation to the EU administration, but should in turn be able to shape the apex of the Commission and thus implement its policy agenda through the EU bureaucracy. ${ }^{246}$

Second, the President of the European Council should be empowered to veto legislation adopted by the European Parliament and the Council, subject to the possibility for the EU legislature (Parliament plus Council) to override the veto with a supermajority of the votes cast. This authority would entrench the ability of the presidency to also act for the protection of the EU federal compact. In fact, as experience has demonstrated, the European Union currently lacks an institution that

242. See, e.g., LouIS FISCher, PResidenTial WAR PoWer 12-16 (2d ed. rev. 2004) (outlining the origin and development of the U.S. President's role as commander in chief of the U.S. armed forces); Bernard Chantebout, La dissuasion nucleaire et le pouvoir présidentiel, 38 PouvoIRS 21 (1986) (discussing the powers of France's president, specifically the power to engage in nuclear deterrence).

243. See TEU, supra note 3 , art. 4(2) (stating that "national security remains the sole responsibility of each Member State").

244. For an accounting of the costs occasioned by the lack of a single EU security and defense policy, see generally VALERIO BRIANI, The Costs of Non-Europe in the Defence Field, (Ctr. for Studies on Federalism \& Instituto Affari Internazionali Paper 2013), available at $\mathrm{http}: / / \mathrm{www}$.iai.it/sites/default/files/CSF-IAI_noneuropedefence_april2013.pdf.

245. See Damian Chalmers, The European Redistributive State and a European Law of Struggle, 18 EUR. L.J. 667, 686-692 (2012) (stressing the importance of legitimizing actions by the Commission in light of its increasing powers).

246. See ceteris paribus Stephen SkowroneK, The Politics Presidents Make: LEADERSHIP FROM JOHN ADAMS TO BILL CLINTON (1997) (giving a historical account of the power of the U.S. presidency to shape U.S. politics through the administration). 
can effectively police the principle of subsidiarity. ${ }^{247}$ While the Commission and the European Court of Justice have a pro-European bias, the European Parliament and the Council also have an interest in adopting EU legislation to expand their competence. ${ }^{248}$ Protocol No. 2 to the EU treaties sought to enlist national parliaments as watchdogs of subsidiarity, but practice has shown that national legislatures have abused their role, mostly for petty domestic politics. ${ }^{249}$ On the contrary, a reformed President of the European Council could be more sensitive to subsidiarity: the expansion of EU legislation would not necessarily aggrandize the presidency, and its subjection to direct popular election would make it prone to exercise veto against EU legislation that encroaches on the powers of the states. ${ }^{250}$

Instead, the new EU presidency should not be empowered to dissolve the European Parliament. In the current EU system of government, the European Council and the European Parliament are strictly separated. This institutional solution should be maintained.251 While a President of the European Council elected by the EU citizens in the EU member states would obviously hold great authority, the separation between the executive and the legislature provides an

247. See TEU, supra note 3, art. 5(3) ("[I]n areas which do not fall within its exclusive competence, the Union shall act only if and insofar as the objectives of the proposed action cannot be sufficiently achieved by the member states, either at central level or at regional and local level, but can rather, by reason of the scale or effects of the proposed action, be better achieved at Union level."); see generally Federico Fabbrini, The Principle of Subsidiarity, in OXFORD PRINCIPLES OF EU LAW (Takis Tridimas \& Robert Schütze eds., forthcoming 2015) (providing a legal analysis of the concept of subsidiarity, exploring its philosophical foundations, and analyzing the particular institutional mechanisms used to secure it).

248. See supra p. 308 (discussing the continuing centralization of EU power).

249. Federico Fabbrini \& Katarzyna Granat, "Yellow Card, But No Foul": The Role of the National Parliaments Under the Subsidiarity Protocol and the Commission Proposal for an EU Regulation on the Right to Strike, 50 COMM. MKT. L. REV. 115, 121-25 (2013) (arguing that vesting veto power in national parliaments is not an effective means to police subsidiarity, because, among other reasons, national legislatures use their power for domestic political reasons).

250. Comparative analysis furnishes cautionary tales in this regard. In the United States, for instance, presidents have often fostered centralization of power. See KoLLMAN, supra note 225; But see also Andrew Jackson, Veto Message to the Senate, July 10, 1832, in A COMPILATION of THE MEsSages and PAPERS OF THE PRESIDENTS 1139-54, available at http:/avalon.law.yale.edu/19th_century/ajveto01.asp (vetoing the bill renewing the charter of the Second Bank of the United States because "modifications of the existing charter proposed by this act are not such, in my view, as make it consistent with the rights of the States or the liberties of the people.").

251. On the separation of powers, see supra p. 303. On the impeachment of the executive, see infra p. 321. 
important wall against potential abuses by the presidency. ${ }^{252}$ Moreover, the presidency should not be endowed with any emergency power. As the comparative experience of South American political regimes demonstrate, in presidential systems in which the legislature is elected through proportional representation, presidents can abuse emergency power when they want to overcome deadlock in the legislature. ${ }^{253}$ This is one of the vices of presidential government that an enlightened reform of the EU system of governance should obviously avoid by restricting the power of the presidency to act within the constitutional framework. On the other hand, I suggest that the term of office of the President should be changed to five years, ${ }^{254}$ renewable once, thus ensuring that the presidency can have a sufficiently broad timeframe of action to carry forward its agenda.

\section{ASYMMETRIES AND ELECTION}

A central question in the proposal to strengthen the presidency of the European Council concerns the mode of its election. This point does not constitute a simple technical feature, but rather raises one of the key constitutional challenges in the process of institutional design of a reformed presidency. ${ }^{255}$ The reason has to do with the profound asymmetry that characterizes the EU member states in terms of population size. As it is well known, the European Union features member states that range in population from Germany, with almost eighty-two million citizens, to Malta, with just over 400,000 inhabitants. ${ }^{256}$ Moreover, 53.5 percent of the 507 million EU citizens live in just four EU member states: Germany, France, the United Kingdom, and Italy; the remaining 46.5 percent is scattered across the other twenty-four member states. This remarkable difference between the population of large and small states defies any easy option for a simple, Europe-wide election of the President of the European Council. Inevitably, such an electoral system would render meaningless the value of voting in the smaller member states, making the election of the President of the European Council a matter exclusively for the larger

252. See Neal Katyal, Internal Separation of Powers: Checking Today's Most Dangerous Branch from Within, 115 YALE L.J. 2314 (2006) (characterizing the U.S. executive as the most dangerous branch of the U.S. government today).

253. See generally The FaILURe of PRESIDEnTLAL Democracy: The CASE of LatiN AMERICA, VoLUME 2 (Juan Linz \& Arturo Valenzuela eds., 1994).

254. This would make the length of the presidential term correspond to the length of the parliamentary term. See supra p. 298.

255. See generally COMPARATIVE CONSTITUTIONAL DESIGN (Tom Ginsburg ed., 2014) (describing institutional choices in constitution-making).

256. EUROSTAT, supra note 28. 
member states. ${ }^{257}$ Incidentally, as explained above, this is exactly the problem associated with the proposal to strengthen the President of the European Commission along the logic where a parliamentary majority selects the chief executive. ${ }^{258}$ Such a solution should not be acceptable considering that the proposal to strengthen the presidency of the European Council is primarily geared toward reestablishing a balance between the member states. ${ }^{259}$

However, the challenge that the European Union is facing is not unique. Most federal systems characterized by uneven geographical units and population imbalances have faced the analogous problem of how to reconcile the desire for shared rule with the need to reassure the smaller member states that their interest will not be unduly sacrificed in the union. ${ }^{260}$ As such, comparative studies provide a wealth of insight that can be taken into account when thinking about EU institutional reform. ${ }^{261}$ For example, to deal with this problem, Switzerland historically developed the principle of double-majority: ${ }^{262}$ while Switzerland does not have a monocratic executive, ${ }^{263}$ popular referenda, which are a pervasive feature of Swiss politics, ${ }^{264}$ require for approval both a majority of the Swiss population and a majority of the Cantons. ${ }^{265}$ The logic of the double majority has been readapted with the specific aim to select a monocratic chief executive in Indonesia, which is a federalizing system with a presidential regime. Pursuant to the Indonesian Constitution, as amended in 2001 in the complex transition

257. See generally Fabbrini, supra note 20.

258. See supra pp. 295-96.

259. See supra p. 306.

260. See Daniel J. Elazar, Exploring Federalism 5 (1987) (stating that federalism involves "the combination of self-rule and shared rule.").

261. See generally FEDERAL Democracies (Michael Burgess \& Alain Gagnon eds., 2010) (describing comparative approaches to creating democracy in federal systems and what may be gleaned from them).

262. Wolf Linder \& Adrian Vatter, Institutions and Outcomes of Swiss Federalism: The Role of Cantons in Swiss Politics, in THE SwISS LABYRINTH 95, 97-99 (Jan-Erik Lane ed., 2001).

263. See Bundesverfassung [BV] [CONSTITUTION] Apr. 18, 1999, SR 101, arts. 174-79 (Switz.) (stating that the seven-member Directorate is elected by the Federal Parliament for a fixed term of four years, and cannot be removed by Parliament). See also HANSPETER Kriesi \& AlEXander H. TREChSEL, THE Politics of Switzerland: Continuity and Change IN A Consensus DemocracY (2008) (explaining that the members of the Directorates are elected on the basis of a rigid formula reflecting the consociational nature of the Swiss system).

264. See Max Frenkel, The Communal Basis of Swiss Liberty, 23 PUBLUS 61, 67 (1993).

265. See Bundesverfassung [BV] [CONSTITUTION] Apr. 18, 1999, SR 101, art. 142 (Switz.). 
toward democracy, ${ }^{266}$ a winning presidential candidate must receive a majority of the popular vote nationwide and at least 20 percent of the vote in a majority of the provinces. ${ }^{267}$

Perhaps the most well-known example of a creative institutional mechanism designed to account for the asymmetries between large and small states in the election of a chief executive is the electoral college of the U.S. Constitution. ${ }^{268}$ As Shlomo Slonim has explained, in the late eighteenth century the majority of the U.S. states provided for the election of the executive by the legislature, ${ }^{269}$ or by direct popular suffrage. ${ }^{270}$ Yet, to the Framers of the U.S. Constitution, neither of these solutions appeared consistent with the objective to secure a separation of powers between the executive and the legislature, as well as to overcome the cleavage between the small and large states, which influenced the entire work of the Philadelphia Convention. ${ }^{271}$ Hence, the Framers came up with something entirely new: the Electoral College. ${ }^{272}$ Pursuant to this system, the President of the United States is not elected directly by the people, but rather he is elected by special electors appointed by-in fact, since the nineteenth century, elected in-the states and constituting together an ad hoc College. ${ }^{273}$ Each state is entitled to a number of electors equal to the sum of representatives and senators that the state possesses in Congress. ${ }^{274}$ Because, pursuant to the Great Compromise, the U.S. Constitution awards every state two senators $^{275}$ and at least one representative, ${ }^{276}$ (regardless of population),

266. See James Giggacher, Stand-Off as Indonesia Treads New Democratic Path, THE CANBERRA TIMES (July 11, 2014) (discussing contested presidential election in 2014).

267. Constitution of THE REPUBLIC OF InDONESIA, Aug. 11, 2002, art. 6A.

268. BRUCE ACKerman, We the PeOple. Volume 1: Foundations 68 (1991).

269. "Election of the executive by the legislature was provided for under the constitutions of Delaware, Georgia, Maryland, North Carolina, New Jersey, Pennsylvania, South Carolina and Virginia." Shlomo Slonim, The Electoral College at Philadelphia: The Evolution of an Ad Hoc Congress for the Selection of a President, 73 J. AM. HIST. 35, 37 n.6 (1986).

270. "Popular election of the executive was provided for under the constitutions of Massachusetts, New Hampshire and New York." Id.

271. For the importance of separation of powers to the Framers of the U.S. Constitution, see Ray Raphael, Mr. President: How and Why the Founders Created a Chief EXECUTIVE 79-80 (2012); GoRdon S. WOOD, THE CREATION OF THE AMERICAN REPUBLIC: 1776-1787, at 547-53 (1993). For the centrality of the division between large and small states, see RAPHAEL, supra, at 108-09; WOOD, supra, at 558-59.

272. U.S. CoNST. art. II, $\S 1$, cls. $2-3$, (establishing the Electoral College).

273. See generally L. PAIGE WhitakeR \& ThOMAS H. NEALE, Cong. REsearch SERV., RL30804, The Electoral COLLEgE: AN OVERVIEW AND ANALYSIS OF REFORM PROPOSALS 1-5 (2001) (providing an overview of the history and current functioning of the electoral college).

274. U.S. CoNST. art. II, $\S 1$, cl. 2.

275. U.S. CoNST. art. I, $\S 3$, cl. 1 . 
the Electoral College secures a slight overrepresentation of the small states in the election of the U.S. President. 277 Hence, whereas the electoral system follows a majoritarian logic (because a candidate must win a majority of the Electoral College votes to be elected President), "the deviation from population apportionment of the electoral college is justified in order to serve federalism." 278

Needless to say, the Electoral College system has received frequent criticism, being the feature of the U.S. Constitution that has been the target of the greatest number of proposed constitutional amendments. ${ }^{279}$ To begin, as Bruce Ackerman has explained, ${ }^{280}$ the Framers of the U.S. Constitution utterly failed to anticipate the rise of presidential democracy and were ingenuous in writing several technical characteristics of the mechanics of the Electoral College. In particular, the Framers envisioned that in the absence of a majority winner in the Electoral College, the election of the President would be thrown to the House of Representatives, where votes would be cast by states (the representation of each state having one vote). ${ }^{281}$ In the election of 1800 , just thirteen years after the adoption of the U.S. Constitution, this resulted in a major constitutional crisis, only haphazardly solved with the election of President Jefferson ${ }^{282}$ and the subsequent adoption of the Twelfth Amendment. ${ }^{283}$ Moreover, the functioning of the Electoral College has continued to raise objections in the present day mainly

276. U.S. CoNST. art. I, § 2, cl. 3.

277. See RAPHAEL, supra note 271 , at 109.

278. Norman R. Williams, Reforming the Electoral College: Federalism, Majoritarianism and the Perils of Subconstitutional Change, 100 GEo. L.J. 173, 192 (2011).

279. See Slonim, supra note 269 , at 35 (reporting that "[c]lose to seven hundred proposals to amend the Electoral College scheme have been introduced into Congress since the Constitution was inaugurated."); Williams, supra note 278 , at 175 (stating that "[i]n the past two centuries, more proposed constitutional amendments have sought to replace or reform the Electoral College than any other feature of [the U.S.] constitutional order.").

280. See Bruce Ackerman, The fallure of the Founding Fathers: Jefferson, Marshall and the Rise of PResidential Democracy 5 (2005) (detailing the electoral college crisis of 1800 ).

281. See U.S. ConST. art. II, § 1, cl. 3.

282. See ACKERMAN, supra note 268, at 104-107 (recalling the popular victory of Thomas Jefferson and his Republican Party in the elections of 1800 but explaining that the electors, due to technical failures in the Electoral College scheme, cast the same number of ballots to Jefferson and his running mate, Aaron Burr, which deprived the former of the Electoral College majority and threw the election to the House of Representatives, which, voting by states, eventually awarded the presidency to Jefferson only after thirty-six inconclusive ballots).

283. See U.S. CoNST., amend. XII (modifying the rules on the functioning of the Electoral College so that the electors separately vote for the president and the vice president). 
because of the possibility that a candidate could become President of the United States by winning the votes of the Electoral College while losing the national popular vote, ${ }^{284}$ an issue which was recently revived in the contested election of $2000 .{ }^{285}$ As a result of the weaknesses of the U.S. Electoral College system, which are objects of ongoing proposals for reform, including through an interstate compact, ${ }^{286}$ it would be unreasonable to advocate its establishment in the European Union for the potential election of the President of the European Council.

However, even if the institution of the Electoral College should not be replicated in Europe, there is one lesson that the system can offer to the European Union: an innovative mechanism to count votes to overcome the asymmetries between the member states in the election of the President. This is achieved by entitling every state to a number of votes corresponding to the sum of votes it enjoys in the two branches of the legislature. The European Union has a bicameral legislature: the European Parliament, which represents the citizens, and the Council, which represents the states. ${ }^{287}$ In the European Parliament, the 751 seats are apportioned on the basis of population, albeit corrected by the principle of degressive proportionality. ${ }^{288}$ As provided by Article 14(2) of the TEU, no member state shall be allocated more than ninety-six seats, and no state shall have less than six. In the Council, until November $2014,{ }^{289}$ votes were weighted between the member states based on their size, but with greater equality in the apportionment between states than in the European Parliament. ${ }^{290}$ In particular, since the accession of Croatia to the European Union in July 2013, ${ }^{291}$ the Council has 352 votes, which are divided between the twenty-eight member states along a ratio, which ranges from twenty-nine votes (for Germany, France,

284. See SANFORd LEVINSON, OUR UNDEMOCRATIC CONSTITUTION 87 (2006).

285. See Bush v. Gore, 531 U.S. 98 (2000) (halting recount of votes in Florida and de facto awarding the presidency to George W. Bush); see also BUSH V. GORE: THE QUESTION OF LEGITIMACY (Bruce Ackerman ed., 2002) (analyzing various legal aspects of the 2000 election).

286. See U.S. CONST. art. $1, \S 10$, cl. 3 (authorizing states to enter into compacts with the consent of Congress); see also Akhil Amar \& Vikram Amar, How to Achieve Direct National Election of the President Without Amending the Constitution, FINDLAW (Dec. 28, 2001), http://writ.news.findlaw.com/amar/20011228.html; National Popular Vote Compact, NATIONAL POPULAR VOTE, http://www.nationalpopularvote.com/ (last visited Aug. 9, 2014) (proposing to award the Electoral College votes to the candidate who wins a majority of the national popular vote).

287. See VAN GERVEN, supra note 219 , at 332 .

288. See TEU, supra note 3 , art. 14(2).

289. See infra p. 320.

290. See TEU, supra note 3, art. 16(4).

291. Treaty Concerning the Accession of the Republic of Croatia to the European Union, Nov. 7, 2011, 2012 O.J. (L 112) 10. 
Italy, and the United Kingdom) to three votes for Malta. ${ }^{292}$ In other words, contrary to the United States, which has one chamber of the legislature (the House) mainly reflecting states' population and one chamber (the Senate) purely enshrining the equality of the states, the European Union is endowed with a bicameral system which incorporates a logic of degressive proportionality in both chambers. Yet, the result is the same: namely to temper majoritarianism to safeguard federalism. This is highly valuable for the purpose of electing the President of the European Council.

My proposal for the mode of election would be the following. Every five years, on the same day EU citizens vote for the European Parliament, they also elect the President of the European Council. Political parties bring forward candidates for the post (possibly through a popular selection process via primaries elections). ${ }^{293}$ Citizens directly vote for the President so there is no special, intermediate electoral body such as the U.S. Electoral College. However, the election of the President is not made on the basis of an EU-wide constituency. Rather, as is the case for the election of the European Parliament, citizens vote in state constituencies. Moreover, (like in the United States) every EU member state is awarded a number of "votes" for the election of the President of the European Council, which equals the number of seats that state has in the European Parliament plus the number of votes that state has in the Council. The candidate that comes first in one state would gain all the "electoral votes" of that state (following the logic of the winner takes all). To be elected President of the European Council, a candidate must obtain the majority of "electoral votes" across the European Union: since the European Parliament has 751 seats and the Council 352 votes, the total number of presidential votes is the sum of 751 and 352, which equals 1,103: so the magic number a candidate must reach to be elected is 1,103 divided by two, which equals 552 . If none of the candidates reaches the majority of 552 votes, the two candidates with the highest number of electoral votes will be subject to a runoff fourteen days after the first election. The candidate who gains a majority of electoral votes will become President of the European Council.

292. See Protocol No. 36 on Transitional Provisions, art. 3(3), 2012 O.J. (C 326) 323, amended by Treaty Concerning the Accession of the Republic of Croatia to the European Union, Nov. 7, 2011, 2012 O.J. (L 112) 20.

293. This is an important point that I cannot develop in full here. But see ceteris paribus Sonia Piedrafita \& Vilde Renman, The 'Personalisation' of the European Elections: A Halfhearted Attempt to Increase Turnout and Democratic Legitimacy?, 37 EUR. POL'Y INST. NETWORK 1, 5 (2014) (raising concerns on the process which has been followed by some European political parties to select the Spitzenkandidaten for the post of Commission President and demanding a more open and transparent process in the future). 
The electoral mechanism proposed here, while being inspired by the trials and errors of regimes abroad, 294 presents several distinctive advantages. Like the U.S. precedent, ${ }^{295}$ it devises a way to count votes, which ensures (through the trick of the "electoral votes") a slight overrepresentation of smaller member states in the selection of the President of the European Council. This addresses the dire problem of asymmetry between large and small states that characterizes the European Union. However, unlike the United States, it removes the filter of an ad hoc electoral body, the Electoral College: whereas the Framers of the U.S. Constitution, with their distrust for radical democracy, ${ }^{296}$ were afraid of a direct, popular legitimation of the executive, this issue seems less of a problem today. Moreover, the option proposed above introduces a runoff mechanism, which has two advantages. First, it allows every political party to present a candidate in the first round of election (which is consistent with the mode of direct election of heads of states in EU member states with semipresidential systems, ${ }^{297}$ and conforms to the logic of proportional representation which is in place for the multi-party European Parliament). ${ }^{298}$ Yet-and this is the second advantage-it also secures through the runoff that the President of the European Council will be elected by a majority (rather than simply a plurality). ${ }^{299}$ As the recent experience of the selection of the President of the European Commission demonstrates, the lead candidate of a party, which represents a plurality in the European Parliament, but only has 29 percent of the EU-wide popular votes, suffers from a legitimacy deficit. ${ }^{300}$ Instead, an electoral mechanism, which secures majority election, (at the latest in the runoff) would boost

294. See generally Mark Tushnet, The Possibilities of Comparative Constitutional Law, 108 YALE L.J. 1225 (1999) (discussing the role of comparative law in designing constitutional solutions).

295. See Williams, supra note 278 , at 192.

296. See WooD, supra note 271 , at 322 .

297. See 1958 CONST. art. 7 (Fr.) (stating that the President of the Republic is elected by absolute majority and if that no candidate obtains this majority in the first ballot, a runoff is arranged between the two most voted candidates after fourteen days); see also CONSTITUTION OF POLAND, art. 127(4) (Pl.) (same rules).

298. See Lori Thorlakson, Federalism and the European Party System, 12 J. EUR. PUB. POL'Y 468, 468-70 (2005) (discussing the application of a framework from comparative federalism to the European party system).

299. Note that in the functioning of the U.S. Electoral College there is the possibility that no candidate reaches a majority of the Electoral College votes. In this case, the election decision is thrown to the House of Representatives. This happened twice in U.S. history: in 1800 and 1824. See LAWRENCE D. LONGLEY \& NEIL R. PEIRCE, THE ELECTORAL COLLEGE PRIMER 118 (1996); see also ACKERMAN, supra note 268, at 104-07.

300. See supra p. 307 and note 233 . 
the claim of the President of the European Council to speak for the European Union as a whole. ${ }^{301}$

With that said, however, I am also aware that my proposal has weaknesses. By trading in a purely majoritarian logic to guard the federal balance between the states, the proposal outlined above disappoints those who would like to see a President directly elected through an EU-wide popular election in which states have no role. ${ }^{302}$ Moreover, the proposal partially builds on the allocation of votes between the member states in the Council traditionally provided for in the EU treaties, and which the Lisbon Treaty has extended on a temporary basis. ${ }^{303}$ However, such a system has been the object of criticism because it significantly distorts the weights of the states by securing a major overrepresentation of middle size EU member states, at the expenses of both larger and smaller ones. ${ }^{304}$ In particular, following the revisions introduced by the Nice Treaty of 2001, Spain and Poland gained as many as twenty-seven votes, only two votes less than Germany (which has twenty-nine votes), despite the fact that these states have respectively 56 percent and 46 percent of the population of Germany. It is also for this reason that the Lisbon Treaty, after a transitional period ending in November 2014, and extendable until March 2017,305 has replaced the current weighing of votes between states in the Council with a Swiss-like "double majority" principle. ${ }^{306}$ Pursuant to Article 16(4) of the TEU, after the end of the transitional period "a qualified majority shall be defined as at least 55 percent of the members of the Council, comprising at least fifteen of them and representing member states comprising at least 65 percent of the population of the Union." Resorting to the weighing of votes in the Council is of course a limit of the proposal. One could think ways to

301. On the connection between electoral mechanisms and government stability, see SARTORI, supra note 199 , at 27.

302. For the proposal for the direct election of the president of the European Commission, see Decker \& Sonnicksen, supra note 182, at 30.

303. See TEU, supra note 3, art. 16(5); see also Protocol No. 36 on Transitional Provisions, art. 3(3), 2012 O.J. (C 326) 323.

304. See Bela Plechanovová, The Treaty of Nice and the Distribution of the Votes in the Council - Voting Power Consequences for the EU after the Oncoming Enlargement, 7 EUR. INTEGRATION ONLINE PAPERS 1 (2003), http://eiop.or.at/eiop/texte/2003-006a.htm.

305. See TEU, supra note 3 , art. 16.

306. See Frank Häge, The Lisbon Treaty's Change to Council Voting Rules Will Have Important Implications for the Democratic Legitimacy of the EU, LONDON SCHOOL ECONOMICS BLOG (Feb. 3, 2014), http://blogs.lse.ac.UK/europpblog/2014/02/03/the-lisbontreatys-change-to-council-voting-rules-will-have-important-implications-for-thedemocratic-legitimacy-of-the-eu. 
reapportion the numbers for the future, but for the moment I have taken what was available and built on it. ${ }^{307}$

Finally-and perhaps more importantly-the proposal to directly elect the President of the European Council deprives the heads of states and government congressed in the European Council of one of their greatest privileges: electing the President. ${ }^{308}$ At the same time, if the election of the President is taken away from the European Council, it is advisable that the power to impeach and remove the President in case of grave misbehaviors be removed from the European Council and attributed to the EU legislature, as a way to secure separation of powers and interinstitutional checks and balances. ${ }^{309}$ As I have explained above, the whole logic of taking the election of the President of the European Council out of the hands of the heads of states and government in the European Council is motivated by the desire to endow the presidency of greater power and legitimacy, to prevent dynamics of interstate dominations, and to create a forum in which alternative policy agenda for the future of the European Union can genuinely compete. ${ }^{310}$ However, it is clear that for a proposal of the direct election of the President of the European Council to succeed, sweeteners should be conceived to compensate the heads of state and government in European Council for the loss of their privilege. ${ }^{311}$ This leads to the next challenge: whether an institutional reform introducing the election of the European Council President would be feasible and what bargaining chips could be considered to make it happen.

\section{UNANIMITY, CONSENSUS, AND COMPROMISE}

In this article, I have made the case in favor of strengthening the role of the President of the European Council as a way to address the dynamic of interstate domination unleashed by the Euro-crisis and revealed by the policy of austerity. In the previous parts, I have

307. An alternative option would be to work around the "double majority" system, as foreseen in Indonesia. See supra p. 315.

308. Alternatively see SERGIO FABBRINI, supra note 144 (proposing an electoral system in which the European Council identifies two candidates, which are then subject to a vote by an electoral college composed of members of national parliaments. This solution would keep the European Council at the helm of the choice of the President but may not remove the problem of interstate domination that has so far characterized the working of the European Council.).

309. See ceteris paribus MICHAEL J. GERHARDT, THE FEDERAL IMPEACHMENT Process: A CONSTITUTIONAL AND HISTORICAL ANALYSIS xi-xii (2d ed. 2000) (emphasizing connection between the impeachment process and separation of powers).

310. See supra Part III .

311. See CRAIG, supra note 151 , at 109. 
envisioned the powers and responsibilities of a new presidency and suggested an electoral mechanism through which the member states and EU citizens could select the President. Now, a pressing question that must be addressed is whether anything that $I$ have argued for has any, even remote, chance of being considered as an option for institutional reform. As scholars, it is possible to fantasize about major constitutional models, and libraries are filled with perfectly designed charters of government that no policy maker has ever considered. ${ }^{312} \mathrm{I}$ will never deny that this is a noble and important task. However, I submit that the interest of my proposal for institutional reform increases to the extent to which it stands a chance of being considered as a feasible option by policy makers. This part attempts to do this. Yet, as a starter it is hard to deny a rocky problem: the challenge of unanimity. Crudely put, the proposal to strengthen the presidency of the European Council would require a change of the EU Treaties and no such change can be made unless the EU member states unanimously concur. 313

However, as much as the process of treaty change in the European Union is a burdensome task, it is not as burdensome as changing the U.S. Constitution. ${ }^{314}$ During the last twenty-two years, the EU treaties have been subject to four major overhauls (excluding the failed attempt to adopt a Treaty Establishing the European Constitution). ${ }^{315}$ The Treaty of Maastricht of 1992, the Treaty of Amsterdam of 1996, the Treaty of Nice of 2001, and the Treaty of Lisbon of 2007 have all introduced profound changes to the architecture of the European Union-leading Bruno de Witte to speak of a "semi-permanent treaty revision process" in the European Union. ${ }^{316}$ Moreover, whereas the Treaty of Lisbon was initially described as the last effort by the EU member states to change the constitutional system of the European

312. See, e.g., the fascinating essay by MELCHIORRE GIOIA, QUALE DEI GOVERNI LIBERI MEGLIO CONVENGA ALLA FELICITÀ DELL'ITALIA (1797) (outlining a constitutional model for the form of government of Italy in 1797). Italy was established as a state only sixty-four years later, in 1861. Interestingly, as explained by AUGUSTO BARBERA, LE BASI FILOSOFICHE DEL COSTITUZIONALISMO 22 (1997), the essay by Melchiorre Gioia was drafted for a public competition promoted by the government of Lombardy, before the region was conquered by Napoleon and made by the French authorities part of a newly created puppet state: the Cisalpine Republic.

313. See TEU, supra note 3, art. 48.

314. See Michael B. Rappaport, Reforming Article V: The Problems Created by the National Convention Method and How to Fix Them, 96 VA. L. REV. 1509 (2010) (explaining the quasi-impossibility of changing the U.S. Constitution).

315. See GIUSEPPE Floridia, Il CANTIERE DELLA NUOVA EUROPA 400 (2003).

316. Bruno De Witte, The Closest Thing to a Constitutional Conversation in Europe: The Semi-Permanent Treaty Revision Process, in CONVERGENCE AND DIVERGENCE IN EuROPEAN PUBLIC LAW 39, 39 (Neil Walker et al. eds., 2002). 
Union in a generation, ${ }^{317}$ the ink of that treaty text was barely dried when the member state exploited the newly introduced "simplified treaty revision procedure" 318 to rewrite Article 136 of the TFEU and allow for the establishment of a permanent stability mechanism for the Eurozone-the European Stability Mechanism (ESM). ${ }^{319}$

Otherwise, as several scholars have underlined, one of the recurrent features of the responses to the Euro-crisis has been the determination of the EU member states, especially of the (now) nineteen Eurozone member states, to adopt international treaties outside the EU legal order but functionally and substantially connected to EU law. ${ }^{320}$ Whether such action was motivated by real legal arguments (such as the lack of legal basis to act within the EU treaties) ${ }^{321}$ or rather by pragmatic concerns (such as the willingness of the majority of the EU member states to sidestep the veto against EU treaty reform by a minority of states, ${ }^{322}$ or the willingness of some member states to bypass the prerogative of the European Parliament in the legislative realm), 323 the widespread use of international treaties by the EU member states during the last four years testifies to the existence of a political will among the EU member states' government to engage in treaty making

317. See Jean Francois-Poncet, Rapport d'information fait au nom de la Commission des Affaires étrangères, de la défense et des forces armées sur le Traité de Lisbonne [Informational Report on the Lisbon Treaty on behalf of the Commission on Foreign Affairs, the Defense and Armed Forces], at 14 (Jan. 30, 2008) (explaining difficulties in moving ahead with the Lisbon Treaty, after the échec of the Constitutional Treaty).

318. See TEU, supra note 3, art. 48(6) (which allows the European Council to adopt a unanimous decision amending all or part of the provisions of Part III of the TFEU-except a decision expanding the competences of the EU-subject to consultation of the European Parliament and the European Commission and approval by every member state in accordance with its domestic constitutional requirement).

319. See European Council Decision 199/2011, art. 1, 2011 O.J. (L 91) 2 (EU) (amending TFEU Article 136 with regard to a stability mechanism for member states whose currency is the euro).

320. See generally KAARLO TUORI \& KLAUS TUORI, THE EUROzone CRISIS: A CONSTITUTIONAL ANALYSIS (2014). See also Frédéric Allemand \& Francesco Martucci, La nouvelle gouvernance économique européene, in 17 CAHIERS DE DROIT ÉUROPÉEN 409 (2012).

321. See TEU, supra note 3 , art. 5 (stating that the competences of the Union "are governed by the principle of conferral").

322. See Bruno De Witte, Using International Law in the Euro Crisis (Univ. of Oslo Ctr. for Eur. Stud., Arena Working Paper No. 4, 2013) (explaining adoption of the Fiscal Compact via international law as a way to side-step the U.K. veto).

323. See generally Federico Fabbrini, On Banks, Courts and International Law: The Intergovernmental Agreement on the Single Resolution Fund in Context, 21 MAASTRICHT J. EUR. \& CoMP. L. 444 (2014) (criticizing the adoption of the Agreement on the Single Resolution Fund as a circumvention of the legislative powers of the European Parliament). 
to reform the EMU. ${ }^{324}$ Although most of the measures adopted by the EU member states via international treaties could arguably be adopted within the EU legal order, ${ }^{325}$ both the Fiscal Compact (signed in March 2012 by twenty-five EU member states and now ratified by all of themexcept the United Kingdom), ${ }^{326}$ the ESM Treaty (concluded in March 2012 by the Eurozone member states), ${ }^{327}$ and now the Agreement on the Transfer and Mutualisation of the Contributions to the Single Resolution Fund (signed in May 2014 by all the member states-except the United Kingdom and Sweden), ${ }^{328}$ have introduced relevant reforms to the EMU. ${ }^{329}$

Furthermore, the Fiscal Compact (and now also the Agreement on the Single Resolution Fund) ${ }^{330}$ includes a provision, which may be of particular relevance to the purpose of our discussion. Under the pressure of the delegates of the European Parliament, who joined as observers to the negotiation about the treaty, despite not being involved in drafting it, ${ }^{331}$ the participating member states accepted to insert a final clause in the Fiscal Compact, which reads that

within five years, at most, of the date of entry into force of this Treaty, on the basis of an assessment of the

324. See Bruno Waterfield, Angela Merkel Pushes for EU Treaty Change, THE TELEGRAPH (Brussels) (Oct. 22, 2013), http://www.telegraph.co.UK/news/worldnews/ europe/eu/10397512/Angela-Merkel-pushes-for-EU-treaty-change.html (reporting calls by German Chancellor Merkel to revise the EU Treaties to put the Eurozone on more stable grounds).

325. See Angelos Dimopoulos, The Use of International Law as a Tool for Enhancing Governance in the Eurozone and its Impact on EU Institutional Integrity, in THE CONSTITUTIONALIZATION OF EUROPEAN BUDGETARY CONSTRAINTS 41, 45-49 (Federico Fabbrini et al. eds., 2014).

326. See Treaty on the Stability, Coordination and Governance of the Economic and Monetary Union, Mar. 2, 2012, [hereinafter TSCG], available at http://europeancouncil.europa.eu/media/639235/st00tscg26_en12.pdf.

327. See Treaty Establishing the European Stability Mechanism, Feb. 2, 2012, available at http://www.european-council.europa.eu/media/582311/05-tesm2.en12.pdf.

328. See Agreement on the Transfer and Mutualisation of Contributions to the Single Resolution Fund, May 21, 2014, [hereinafter Agreement SRF], available at http://register.consilium.europa.eu/doc/srv?l=EN\&f=ST\%208457\%202014\%20INIT.

329. See generally Alicia Hinarejos, The Euro AREa CRisis in Constitutional PERSPECTIVE (2015) (examining the issues surrounding the crisis and the legal responses to it).

330. See Agreement SRF, supra note 328, art. 16.

331. See Press Release, European Parliament, Fiscal Union: EP Representatives "Cautiously Optimistic" 1 (Jan. 26, 2012), available at http://www.europarl.europa.eu/pdfs/news/expert/infopress/20120116IPR35406/20120116IP R35406_en.pdf (reporting role of European Parliament negotiators in influencing the drafting of the Fiscal Compact). 
experience with its implementation, the necessary steps shall be taken, in accordance with the Treaty on the European Union and the Treaty on the Functioning of the European Union, with the aim of incorporating the substance of this Treaty into the legal framework of the European Union. ${ }^{332}$

The Fiscal Compact introduces an obligation for the EU member states that signed the treaty to find ways to bring back the content of the treaty into the law of the European Union by January 1, 2018. ${ }^{333}$ Because of the nature of (some of) the legal innovations set by the Fiscal Compact, this implies the necessity to amend the TEU and the TFEU, thus creating a window of opportunity in which the institutional proposal advanced in this article could be seriously taken into consideration. ${ }^{334}$

In fact, whereas the key provision of the Fiscal Compact-the obligation for the member states to introduce a "golden rule" that is a balanced budget rule in their domestic constitutions ${ }^{335}$-would not require a treaty change since it could be adopted through an EU regulation, ${ }^{336}$ there are other provisions which are not consistent with the EU treaties as they currently stand. One of these is the so-called "reversed qualified majority" rule, ${ }^{337}$ pursuant to which the member states in Council commit to approve a decision by the Commission finding a member state in breach of the excessive deficit rule of the SGP unless a qualified majority of member states is opposed to the Commission decision. ${ }^{338}$ According to the current Article 126(6) of the

332. TSCG, supra note 326 , art. 16.

333. See TSCG, supra note 326, art. 14(2). The incorporation of the content of the Agreement on the Single Resolution Fund, which is scheduled to enter into force by January 1, 2016, is instead supposed to occur within ten years, i.e., by January 1, 2026. See Agreement SRF, supra note 328, art. 11.

334. See European Parliament Resolution of 2 February 2012 on the European Council meeting of 30 January 2012, PARL. EUR. Doc. P7_TA(2012)0023 §9, available at http://www.europarl.europa.eu/ sides/getDoc.do?pubRef=-//EP//NONSGML+TA+P7-TA2012-0023+0+DOC+PDF+VO//EN (which "[i]nsists that the contracting parties fully respect their commitment to integrate, within five years at the latest, the Treaty on Stability, Coordination and Governance into the EU treaties and asks for the remaining weaknesses of the Treaty of Lisbon to be tackled on this occasion.").

335. See Fabbrini, supra note 10, at 5.

336. But see TUORI \& TUORI, supra note 320 , at 109 (raising doubts on the possibility to impose "through EU secondary regulation such an obligation to undertake legislative, preferably constitutional, measures").

337. See TSCG, supra note 326, art. 7.

338. See Paul Craig, The Stability, Coordination and Governance Treaty: Principle, Politics and Pragmatism, 37 EUR. L. REV. 231, 234, 244 (2012). 
TFEU, in fact, the opposite rule applies since a qualified majority vote by the Council is necessary to endorse the decision of the Commission. Hence, an amendment of the TFEU would probably be required. ${ }^{339}$ Nevertheless, it is another part of the Fiscal Compact that would certainly compel a treaty revision, if the member states are to obey their obligation to bring back the content of that treaty in the TEU and TFEU: this is Title V of the Fiscal Compact that provides a brand new set of rules for the "Governance of the Euro Area." In particular, Article 12 of the Fiscal Compact institutionalizes the Euro Summit-i.e., the meeting of the heads of state and governments of the Eurozone, jointly with the Presidents of the Commission and the ECB-and creates the post of President of the Euro Summit. 340

The Euro Summit, initially set up as an informal gathering in October 2008 at the initiative of then French President Sarkozy, was given a first structure in a statement adopted in October 2011 by the heads of states and governments of the Eurozone member states. ${ }^{341}$ This statement advanced ten measures to improve the governance of the Euro-area, including the decision to hold regular Euro Summit meetings at least twice a year, establish a post of permanent Euro Summit President, and coordinate the work of the Euro Summit with that of the Eurogroup acting at a lower level in the composition of national ministers of finance. The legal nature of this statement was not clarified, and although part of its content was replicated in the European Council conclusions of October 2011,342 it was uncertain whether the statement could be interpreted as an international agreement concluded by the Eurozone member states. The Fiscal Compact, however, gave the Euro Summit a legal status-officializing the format of the meetings and their composition. ${ }^{343}$ Moreover, it clarified the role of the President of the Euro Summit, which was shaped tout court on the role of the President of European Council set by Article 15 of the TEU. ${ }^{344}$ In March 2012, the heads of state and government of the Eurozone member states decided to entrust the task

339. See Rainer Palmstorfer, The Reverse Majority Voting Under the 'Six Pack': A Bad Turn for the Union?, 20 EUR. L.J. 186, 192, 193 (2014).

340. On the Euro Summit, see Christian Calliess, The Governance Framework of the Eurozone and the Need for a Treaty Reform, in WHAT FORM OF GOVERNMENT FOR THE EUROPEAN UNION AND THE EUROZONE? 37 (Federico Fabbrini et al. eds., 2015).

341. See generally Euro Summit Statement (Oct. 26, 2011), available at http://www.consilium.europa.eu/uedocs/cms_data/docs/pressdata/en/ec/125644.pdf.

342. See European Council Conclusions EUCO 52/1/11 of 23 October 2011, 5.

343. See TSCG, supra note 326, art. 12(1)-(2).

344. See supra p. 298. 
of Euro Summit President to Mr. Van Rompuy, ${ }^{345}$ the then President of the European Council. And in August 2014, when Mr. Tusk was elected as second President of the European Council, he was also appointed as President of the Euro Summit, 346 thus promoting a degree of institutional connection-yet also of confusion-between the European Council, in which all EU member states are involved, and the Euro Summit, in which only a sub-group of states are represented. 347

Leaving aside the question of how the system of institutional governance designed for the Eurozone can be "repatriated" within the TEU, and reconciled with the broader institutional architecture that concerns all the EU member states, ${ }^{348}$ it seems undeniable that the prospect of a treaty reform to reverse engineer the Euro Summit within the TEU offers an attractive opportunity to reconsider the role of the presidency as advocated in this article. ${ }^{349}$ However, there remains a follow up question: why should the member states' governments subscribe to the idea of strengthening the role of the presidency of the European Council? Whereas the Lisbon Treaty has institutionalized the "Convention method" to amend the treaties, ${ }^{350}$ ultimately, pursuant to Article 48 of the TEU, a conference of representatives of the governments of the member states shall be convened by the President of the Council for the purpose of determining by common accord the amendments to be made to the Treaties. The amendments shall enter into force after being ratified by all the member states in accordance with their respective constitutional requirements.

345. See Statement Euro Area Heads of State or Government, at 1 (Mar. 2, 2012), available at $\mathrm{http}: / / \mathrm{www} . c o n s i l i u m . e u r o p a . e u /$ uedocs/cms_data/docs/pressdata/en/ec/128521.pdf.

346. See Decision Heads of State or Government of the Contracting Parties to the TSCG, at 1 (Aug. 30, 3014), available at http://www.parlament.gv.at/PAKT/EU/XXV/EU/03/60/ EU_36040/imfname_10489339.pdf .

347. See Philippe De Schoutheete, The European Council After Van Rompuy, Notre EUR. TRIB. VIEWPOINT, April 20, 2015, available at http://www.institutdelors.eu/media/ europeancouncil-deschoutheete-jdi-april15.pdf?pdf=ok.

348. See generally Brigid Laffan, European Union and Eurozone: How to Co-exist?, in GOVERNANCE FOR THE EUROZONE: INTEGRATION OR DisINTEGRATION? 173 (Franklin Allen et al. eds., 2012) (examining how an "avante garde" Eurozone could develop if norms for all EU member states are not established and followed).

349. See European Parliament Resolution of 20 November 2012 with recommendations to the Commission on the report of the Presidents of the European Council, the European Commission, the European Central Bank and the Eurogroup "Towards a Genuine Economic and Monetary Union," PARL. EUR. DOC. P7_TA(2012)0430 § 6, available at http://www.europarl.europa.eu/sides/getDoc.do?pubRef=-//EP/NONSGML+TA+P7-TA-

2012-0430+0+DOC+PDF+VO//EN (calling for a convention to amend the Treaties).

350. See generally Steve Peers, The Future of EU Treaty Amendments, 31 Y.B. EUR. L. 17 (2012) (explaining the process of revision of the EU Treaties). 
So why should the member states agree to revise the role of the presidency of the European Council? I suggest that the proposal to strengthen the presidency may be particularly attractive to many member states for political reasons. However, I would also advise introducing an institutional expedient to sweeten the change advocated in this article and make it more agreeable for all of them.

From a political perspective, I suspect the idea to strengthen the presidency may be attractive for the small, poor, and new EU member states. As I have previously indicated, the intergovernmental governance of the Euro-crisis during the last year has shattered the expectations of the smaller member states that they could keep control of the European Council and instead unleashed a dynamic of domination by the larger states. ${ }^{351}$ Otherwise, for the countries in dire economic conditions in the southern European Union, the diminution of power has been so significant that the idea of electing the President of the European Council would be a way to regain status in EU decision making. ${ }^{352}$ And for the countries in the eastern European Union, which recently joined the Union and are not yet part of the Eurozone, the strengthening of the President of the European Council would be a way to ensure that they are not cut off from deliberation on the future of the European Union ${ }^{353}$ (not to mention, of course, the added value that a stronger presidency could have for the eastern member states as far as the protection of their interests in foreign affairs and security is concerned). ${ }^{354}$ However, I submit that the proposal to strengthen the President of the European Council could also be advantageous for Italy and France. Although both are large, rich, founding members of the European Union, their influence on the EU agenda setting has greatly diminished..$^{355}$ As seen above, despite efforts to counterbalance German

351. See Fabbrini, supra note 20, at 5 .

352. See generally Lina Papadopoulou, Can Constitutional Rules, Even if 'Golden', Tame Greek Public Debt?, in THE CONSTTTUTIONALIZATION OF EUROPEAN BudgetaRY CONSTRAINTS 223 (Federico Fabbrini et al. eds., 2014) (emphasizing restrictions of sovereignty in Greece).

353. See e.g., Karolina Pomorska \& Sophie Vanhoonacker, Poland in the Driving Seat: $A$ Mature Presidency in Turbulent Times, 50 J. COMMON MKT. STUD. 76 (2012) (emphasizing desire by Poland to be involved in EU decision making).

354. See generally Press Release, North Atlantic Treaty Organization (NATO), Wales Summit Declaration: Issued by the Heads of State and Government Participating in the Meeting of the North Atlantic Council in Wales (Sept. 5, 2014) (emphasizing security concerns in Eastern Europe).

355. See e.g., Adriana Cerretelli, La partita delle nomine che contano a Bruxelles, IL SOLE 24 ORE (July 8, 2014), http://www.ilsole24ore.com/art/notizie/2014-07-08/la-partitanomine-che-contano-bruxelles-063621.shtml?uuid=AB4IzfYB\&fromSearch (reporting decreasing influence of Italian officials at EU level); Jean-Luc Gréau, Peut-on enrayer le déclin économique français?, REVUE POLITIQUe ET PARLAMENTAIRE (Jan. 8, 2014), 
hegemony in the European Council, neither of them has effectively succeeded in its plan. ${ }^{356}$ Strengthening the presidency of the European Council-which would be very much consistent with the domestic tradition of the French form of government ${ }^{357}$-could therefore offer them a preferable alternative to enduring another decade of German domination.

In addition, the idea of a reformed presidency may actually work well for the United Kingdom, if it remains in the Union. ${ }^{358}$ This may seem counterintuitive, since the United Kingdom has always been wary of European Union over-empowerment and protective of its constitutional tradition. ${ }^{359}$ Yet, the idea is not entirely foreign to U.K. preferences, since at the time of the Constitutional Convention the U.K. government had expressed its support for a strengthened presidency of the European Council. ${ }^{360}$ Moreover, as of now, the United Kingdom has had major difficulties in finding an EU institutional forum through which to channel its concerns. The role of the U.K. government in the European Council is weak, and the capacity of U.K. voters to influence through their ballot for the European Parliament the composition and the agenda of the Commission is negligible. ${ }^{361}$ On the contrary, as I have suggested above, the presidency may serve as a brake against supranational encroachments over national prerogative. ${ }^{362}$ Because an elected President of the European Council could speak for the entire European Union, and could make a legitimate claim to protect the federal division of competence, the interests of the United Kingdom could be better secured through this new institutional arrangement

http:/www.revuepolitique.fr/peut-enrayer-le-declin-economique-francais/

(discussing

French economic decline).

356. See supra pp. 282-83.

357. See Magnette, supra note 150, at 1067; Duverger, supra note 187.

358. See European Union (Referendum) Bill, 2012-13, H.C. [11] cl. 1 (U.K.) (stating that a referendum on the U.K.'s membership within the EU will be held before 31 December 2017).

359. See generally European Union Act, 2011, c. 12 (U.K.) (placing restrictions on treaties relating to the EU); Paul Craig, The European Union Act 2011: Locks, Limits and Legality, 28 COMMON MKT. L. REV. 1881 (2011) (discussing the "locks" the U.K. has imposed on its ability to approve EU documents and decisions).

360. CRAIG, supra note 151, at 83 (reporting a January 2003 proposal by the U.K. government advanced during the Constitutional Convention in favor of strengthening the presidency of the European Council).

361. See Toby Helm, Humiliating Defeat for David Cameron Pushes Britain Towards EU Exit, THE GUARDIAN (June 28, 2014), http:/www.theguardian.com/world/2014/jun/28/ cameron-eu-juncker-defeat-britain-exit (reporting increasing isolation of the U.K. government in the European Council).

362. See supra pp. 307-08. 
rather than the current one. ${ }^{363}$ Note also that, following the mechanism of election I articulated above, the United Kingdom would be entitled to 102 "electoral votes" for the choice of the President-and no presidential candidate could afford to disregard the concerns of a constituency that counts for 20 percent of the votes needed to win one-half of the total 1,103 electoral votes.

This of course leaves out Germany. As the reluctant hegemon of the European Union, ${ }^{364}$ and the state that currently sets the tone of the EU policy agenda, Germany would have the most to lose from a proposal to strengthen the presidency of the European Council. Nevertheless, because of its history, Germany also has very much to lose from fueling the popular view that it has, once again, come to dominate the continent. ${ }^{365}$ As such, the burning of a German flag by Greek youngsters in Syntagma Square, Athens, ${ }^{366}$ as well as the proposal by a former President of the European Commission to set up an alliance between France, Italy, and Spain against Germany, ${ }^{367}$ should be cause for concerns in Germany. Hence, my proposal: Germany should take a step back, trade its short-term dominant position for the long-term interest in protecting the sustainability of the Union and accept the plan to directly elect the President of the European Council. With 125 "electoral votes" out of a total of 1,103 , Germany would still be the leading battle state for any presidential candidate that wants to win election. At the same time, the other member states must compensate Germany with a payback: accommodating repeated and legitimate German concerns, ${ }^{368}$ they must accept the writing into the EU treaties of a prohibition to mutualize the debts of the Eurozone member states. The proposals to adopt Euro-bonds or a redemption fund, which are periodically revived in the debate, ${ }^{369}$ are ill conceived because they would ask Germany to

363. See generally Foreign \& COMMONwEALTH OFFICE, REviEw of THE BALANCE of COMPETENCES (2012), available at https://www.gov.uk/review-of-the-balance-of-competences (considering effect of EU competences on U.K. policy).

364. See Paterson, supra note 28, at 57.

365. See Timothy Garton Ash, The New German Question, 60 N.Y. REV. Books, Aug. 15, 2013, at 52, 52-53 (highlighting Germany's "second chance" after WWII and its reluctance to help countries any more than is absolutely necessary).

366. See Wearden, supra note 14.

367. See Damilano, supra note 123.

368. Cf. Merkel Vows 'No Euro Bonds as Long as I Live', DER SPIEGEL ONLINE (June 27, 2012, 9:25 AM), http:/www.spiegel.de/international/europe/chancellor-merkel-vows-noeuro-bonds-as-long-as-she-lives-a-841163.html (reporting strenuous opposition by German Chancellor Angela Merkel against the proposal to create Euro-bonds).

369. Compare Jean-Claude Juncker \& Giulio Tremonti, E-Bonds Would End the Crisis, THE FIN. TIMES (Dec. 5, 2010), http:/www.ft.com/cms/s/0/540d41c2-009f-11e0-aa2900144feab49a.html (arguing in favor of Euro-bonds), with Stijn Claessens et al., Paths to Eurobonds, (Int'l Monetary Fund, Working Paper No. 12/172, 2012) (discussing euro-bond 
pay for the debts of the other member states. ${ }^{370}$ This is unfair and unprecedented, since in no federal system worldwide are debts of one unit horizontally paid by the treasury of another unit. ${ }^{371}$ Ruling out this possibility in the EU treaties would assuage Germany and make it possibly more interested in signing off for a reformed EU presidency.

It goes without saying that what I am suggesting is a great compromise, analogous to the one struck by the United States at the Philadelphia Constitutional Convention:372 Every EU member state gives up something, yet everyone gains something in return, and the Union is better off. Of course, path dependency constitutes a strong obstacle against changing the functioning of the European Council-and it is unlikely that the heads of state and government would be willing to renounce playing a role in EU policy making. ${ }^{373}$ But this claim could be dealt with by envisaging a new role for the congress of states' presidents and prime ministers-e.g., as by transforming the European Council as the real upper legislative house of the European Union, absorbing the legislative functions of the Council. In my view, the operation of the European Council as a collective executive has been unsatisfactory. However, the European Council could perhaps fulfill an important role as a kind of EU Senate. Strengthening the role of the President of the European Council as the real EU executive would then become part of a broader package of reforms-and its success would be linked to a more comprehensive restructuring of the EU institutional architecture based on a healthy constitutional compromise. ${ }^{374}$

proposals as a way to resolve the financial crisis and redefine EU relationships). The recent appointment of Mr. Juncker as President of the European Commission has revived the issue. See Beda Romano, II PSE a Juncker: Lavorare per gli Eurobond, IL SOLE 24 ORE, July 8, 2014 (reporting pressure by the European Socialist Party on President-elect Juncker to revive the proposal to establish euro-bonds).

370. But see Federico Fabbrini, Taxing and Spending in the Eurozone: Legal and Political Challenges Related to the Adoption of the Financial Transaction Tax, 39 EUR. L. REV. 155, 161-62 (2014) (making the case in favor of endowing the European Union with adequate taxing and spending powers, and claiming that an EU fiscal capacity should avoid falling pray of the negative logic of interstate transfers).

371. See Jonathan A. Rodden, Hamilton's Paradox: The Promise and Peril of FISCAL FEDERALISM 6-10 (2006) (explaining that in federal currency unions debts of the local governments are covered-if at all-by the central government but not directly by the other local governments).

372. Jack N. Rakove, The Great Compromise: Ideas, Interests and the Politics of Constitution Making, 44 WM. \& MARY Q. 424, 424-25 (1987) (explaining the process of compromise at the US Constitutional Convention).

373. See Uwe Puetter, New Intergovernmentalism: the European Council and its President, in WhAT FORM OF GOVERNMENT FOR THE EUROPEAN UNION AND THE EUROZONE 253 (Federico Fabbrini et al. eds., 2015).

374. See generally AVISHAI MARGALIT, ON COMPROMISE AND ROTTEN COMPROMISES (2013) (distinguishing between compromises and rotten compromises). 


\section{CONCLUSION}

The European economy is fragile. Speaking at the Euro Summit meeting of October 2014, ECB President Mario Draghi stated that growth in the Eurozone will remain flat if not outright negative in 2014 and 2015, inflation is at an all-time low, while unemployment is unacceptably high-with an average of 11.5 percent of the total workforce without a job and almost 24 percent of young people out of the labor market. ${ }^{375}$ Speaking before the European Parliament in March 2015, after the ECB inaugurated a monetary policy of quantitative easing, ${ }^{376}$ the ECB President sounded slightly more hopeful on the prospects of growth and inflation, but he underlined the still dramatic conditions of the labour market. 377 This is itself a cause for concern. Yet, as this article has suggested, the specific economic condition of the European Union and the resilience of austerity is just the surface of a structural constitutional problem, which is a reason for even greater concern. Austerity has prevailed in the EU responses to the crisis because of the growing imbalance between the EU member states, with Germany playing a central position in the EU decision-making process and promoting its policy preferences throughout the European Union. And this is the result of institutional developments in the EU system of government-finding their roots in the Maastricht Treaty but becoming fully visible during the Euro-crisis-which have seen the European Council (the body congressing the heads of states and governments of the EU member states) rise to the center of EU politics and set the agenda of the European Union as far as economic policy is concerned.

Nevertheless, in an intergovernmental forum such as the European Council, the traditional equilibrium between the member states has been upset, opening the door to a dynamic of interstate domination. Austerity is the evidence of this, but the problem runs deeper. Regardless of whether one is in favor of or against the policy of austerity, an institutional regime in which some member states can dominate the policy-making process and impose their preferences over the others strikes at the heart of the antihegemonic nature of the EU integration project. A Union of states and citizens like the European

375. Mario Draghi, President of the ECB, "Economic Situation in the Euro Area", Presentation at the Euro Summit, (Oct. 24, 2014), available at http://www.ecb.europa.eu/ press/key/date/2014/html/sp141024_1.en.html.

376. Press Release, European Central Bank, ECB Announces Expanded Assets Purchase Programme (Jan. 22, 2015), available at https://www.ecb.europa.eu/press/pr/ date/2015/html/ pr150122_1.en.html.

377. Mario Draghi, President of the ECB, Hearing at the European Parliament's Economic and Monetary Affairs Committee, Introductory Remarks and Q\&A (Mar. 23, 2015), available at https:/www.ecb.europa.eu/press/key/date/2015/html/sp150323_1.en.html. 
Union can only be sustained if all its constitutive parts feel they have a way to influence the decisions that affect them. As the economic responses to the Euro-crisis have made clear, however, austerity has remained resilient in the European Union notwithstanding the increasing protest against, and opposition to, it in many EU member states, because this policy met the approval of the largest state of the European Union and its economic powerhouse: Germany. In this situation, it is not surprising that citizens in many member states have regarded the economic measures mandated by the European Union as illegitimate, and have increasingly voiced their disagreement by casting their ballots for extreme, antisystem parties, openly advocating leaving the Eurozone. When the possibility of voice is limited, exit becomes a viable option. 378

To address this critical state of affairs, this article has advanced the proposal to introduce a targeted institutional reform in the European Union: strengthening the role of the President of the European Council, so as to make it the President of the Union as a whole, along the constitutional logic of separation of powers. If the European Council increasingly becomes the center of EU politics, then, this article proposed that its presidency ought to be endowed with greater powers and legitimacy. Reforming the presidency of the European Council, by increasing its capacity to set the EU agenda (beyond the preferences of a few EU member states) and making it accountable directly to EU citizens (rather than just to the EU heads of states and government) would be instrumental not only to reestablishing a healthy balance between the EU member states, but also to creating a genuine forum for democratic competition on the agenda of the European Union. As I claimed, compared to other options of institutional reform, especially the initiative to boost the politicization of the President of the European Commission along a fusion-of-powers logic, the proposal to strengthen the President of the European Council along a separation-of-powers logic, is better fitting the nature of the European Union as an asymmetrical union of states and citizens.

To support this argument, this article sought to first offer a (certainly incomplete) explanation of what the proposal to strengthen the presidency of the European Council would entail, and then discussed from a comparative constitutional perspective a number of pressing challenges that accompany this proposal for institutional reform.

378. See generally ALBERT O. HIRSChMAN, EXIT, VOICE, LOYALTY: RESPONSES to DECLINE IN FIRMS, ORGANIZATIONS AND STATES (1970). 
First, I considered how a strengthened presidency of the European Council could handle the representation deficit that currently characterizes the EU executive branch and outlined the specific powers that should be attributed to the President. Here I emphasized the advantages that a reformed presidency would produce in terms of equality between the states, unity of the Union, and protection of the federal compact, and recommended that the President be entrusted with the power to shape the Commissioners, to veto EU legislation, butcrucially - not to dissolve the European Parliament. Second, I focused on the modes of election and suggested a possible mechanism to elect the President of the European Council that takes into account the profound asymmetry in population between the EU member states. Here, I discarded the option for an EU-wide popular election and rather proposed that the President be voted on by EU citizens in state constituencies-each of which should be awarded a number of "electoral votes" equal to the number of seats that state has in the European Parliament and the number of votes it weights in the Council-through a majority (rather than plurality) system, with a runoff between the two candidates that received the most votes. Third, I discussed the chances that the proposal outlined above could be taken seriously in the debate about EMU reform and cautiously suggested that a window of opportunity may actually exist. Given the obligation for the EU member states to incorporate the content of the Fiscal Compact within the EU treaties, the idea to strengthen the presidency may be put on the table as an advantageous option for a majority of EU member states, while sweeteners and institutional paybacks ought to be devised to convince the other states, notably Germany, to sign off to the deal.

Ultimately, many challenges cloud the possibility for the European Union to change its constitutional architecture in the direction of strengthening the presidency of the European Council. However, beginning a discussion about the potentials of such an institutional reform seems to be a worthwhile effort. Beyond the policy of austerity, efforts should be made to reform the EU system of governance so that it is no longer subject to dynamics of interstate domination. Strengthening the role of the President of the European Council along the logic of separation of powers can be the most suitable constitutional step to restore an institutional balance and to create a democratic forum for an open and genuine contestation on the agenda of the European Union. 